\title{
EFL Teachers' Perceptions of the Significance of "Four Cs" and Their Suggestions to Enhance "Four Cs" for High School EFL Students in Vietnam
}

\author{
Vuong Thi Huyen Tran ${ }^{1}$ \\ 'Bachelor, School of Foreign Languages, Can Tho University, Vietnam
}

\begin{abstract}
The 21st century learning and innovation skills, known as "Four Cs" (4CS) for a short term have long been highly appreciated for their incontrovertibly enormous benefits for the learners' future success in the process of perceiving knowledge and the accumulation of these four important skills of the $21^{\text {st }}$ century. There have been numerous studies about "four Cs" worldwide so far, but little research on this topic has been conducted in Vietnam. This research aims at investigating high school EFL teachers' perceptions about the significance of "Four Cs" for high school students, exploring their proposals which aim at developing these four skills for high school students. The official participants in the study were 50 high school EFL teachers teaching English from various high schools in An Giang Province. Among those participants, 9 EFL high school teachers took part in semi-structured interviews related to the theme. With a descriptive approach and a method of qualitative research, structured questionnaire and semi-structured interviews which were employed were regarded as two main research instruments. In general, the findings of this study revealed that EFL teachers in high schools in An Giang Province had been highly aware of the important role of "Four Cs" for high school students, and the findings also explored their recommendations to enhance "Four Cs" for high school students in An Giang Province in Vietnam. From the findings, the study suggested some implications to boost "Four Cs" for EFL students. Finally, the limitations and the suggestions for further research were also discussed.
\end{abstract}

Keywords - "four Cs" or 4Cs, important role or significance, EFL teachers' suggestions, enhancing or developing 4 Cs

\section{INTRODUCTION}

As stated in the Partnership for 21st - Century Learning (2011a), the "Four Cs" are the 21st -century learning and innovation skills which should be prepared for students in a classroom in order that they can obtain future success after high school. The "Four Cs" include communication, collaboration, critical thinking, and creativity. From the findings of some previous studies, National Education Association (2015) came to the conclusion that the "Four Cs" need to be fully integrated into the learning and teaching process to produce citizens and employees qualified for the 21 st -century global economy.

According to Dung (2020), the 21st -century is considered an era of the skill-based economy. Human abilities are evaluated in all 3 aspects of knowledge, skills, and attitudes. Teaching soft skills and incorporating them into training programs is quite prevalent around the world. Soft skills, together with experience and foreign languages, are an essential prerequisite for each student during the integration period. Klaus (2010) claimed that only $25 \%$ of successful people who were determined by the professional knowledge and that the remaining $75 \%$ are determined by the soft skills they were equipped with in a proactive, positive way before.

Undoubtedly, we are living in the age of the skill-based economy, and that economic rivalry between nations is based on competencies that meet the current era's criteria. Accordingly, individuals must have the skills necessary to live and operate in a knowledge society where collaboration replaces rivalry, good communication with others is technologically dependent, and broad-minded problem-solving abilities are required (Varis, 2007, as cited in Albahlal, 2019). As a result, education was argued to equip students with the abilities they need to succeed in the twenty-first-century communities and jobs. Several academic institutions have attempted to establish frameworks for determining 21st -century skills and recommending ways to merge these skills into the educational system overall, and English language learning in particular (Brown et al., 2008). Likewise, Erdoğan 
DOI: $\underline{10.51386 / 25815946 / i j s m s-v 4 i 5 p 112}$

Volume: 4 Issue: 5

September to October 2021

https://www.ijsmsjournal.org

(2019) stated that students who leave school without a clear grasp of their abilities and the competencies that our era demands will not be adequately prepared for society's and the workplace's difficulties and obstacles. According to the Partnership for 21st -Century Skills (2011), the "Four Cs" including communication, collaboration, creativity, and critical thinking are regarded as four core learning and innovation skills in the twenty-first century. In addition, Albahlal (2019) suggested that schools in general and English Language classrooms, in particular, should equip students with practices and processes aimed at fostering creativity, critical thinking, collaboration, media literacy, initiative and self-direction, and social and cross-cultural skills, among other things. Furthermore, English classes must be immersed with significant and thought-provoking activities, practices, and processes that enable students to not only effectively articulate thoughts and ideas using oral, written, and nonverbal communication, but also to comprehend complicated viewpoints, use multiple media and technologies, make judgments and decisions, and collaborate creatively with others. Consequently, teachers ought to be conscious of the significance of 21 st-century skills, and the curricula should be adjusted to match 21 st-century demands.

Nonetheless, when looking back at the Vietnamese education system, some things that should be taken care of. These things that need to be discussed especially in English subject are related to the educational objectives and the ways to carry out aims effectively in preparing the learners' skills and knowledge to meet the needs of the 21st century. First of all, it is necessary to master the characteristics of English subject and make full use of the benefits of this subject in order to obtain the objective of the goal of the new General Education Program of the year 2018 and the orientation of the Foreign Language Project 2020 relating to the English subject. According to Hung (2018), as one of the instrumental subjects in high school, English not only helps students form and develop communication skills in English but also contributes to the formation and development of common competencies so that learners can live and work more efficiently, to study other subjects well as to study for a lifetime. English provides students with an important international communication tool, helping them exchange advanced information, scientific and technical knowledge, learn about cultures, thereby contributing to the creation of understanding among peoples, forming a sense of global citizenship, contributes to the development of personal qualities and competencies. Meanwhile, the goal of the new English Program only focuses on the students' communication capacity. In fact, the goal of the new General Education Program of the year 2018 and the orientation of the Foreign Language Project 2020 promulgated by the Ministry of Education and Training of Vietnam, both of which aim to develop the learners' four language skills (including listening, speaking, reading and writing skill) and improve the learners' communication skills towards English subject in particular. Typically, Thanh (2019) pointed out that the new General Education Program's objective is to create and develop the unique capability of the English subject, which is the ability to communicate. Other skills such as collaboration skills, critical thinking and creativity, etc. have not been focused clearly and specifically in the new General Education Program in Vietnam. As a result, high school students are less equipped with the 21st century skills; especially after graduating from high school, they are often confused and lack confidence in the university environment where there is a great need for active students, and sometimes the shortage of soft skills of students after high school graduation leads to failure to meet the job market needs of employers targeting part-time or full-time work. For example, Khang (2013) mentioned a survey by the Ministry of Labor and Social Affairs, in which more than $13 \%$ of students must be retrained or supplemented with soft skills, nearly $40 \%$ must be tutored at work, $41 \%$ need time to get familiar with the job. Similarly, according to (Tapchicongthuong.vn, 2019), Mai (2019) stated that for a person to succeed in life involves talent as well as communication skills, but communication skills are more crucial between the two. It will not keep up with the evolution of society when the education program does not train individuals who are able to do the job immediately. Therefore, new graduates lack too many skills to work, especially "soft" skills such as analytical thinking, synthesis, presentation, communication or teamwork. Ms. Le (as cited in Tapchicongthuong.vn, 2019) said "According to the Ministry of Education and Training, 37\% of graduates are currently unable to find work. We don't lack jobs, but we lack students who can do the job.". Accordingly, education managers, educators and teachers should consider the benefits of other skills such as critical thinking, collaboration and creativity in addition to communication skill to help learners not only attain communication capacity but also develop other skills. According to dantri.com.vn (2016), learners need to be equipped with "Four Cs" skill groups while studying at school so that they will be able to become positive, confident, successful at work and know how to organize their lives. The non-profit Partnership for 21st Century, a leading U.S. policymaker and educator, has studied and identified four essential skill groups (4Cs) for 21 st century children such as communication skills, critical thinking, creativity and collaboration. The 4Cs-focused education approach immediately received global attention and was put into study by thousands of educational institutions and teachers across the U.S. and internationally. The importance of each skill group has been recognized by US educators. First, communication 
DOI: $\underline{10.51386 / 25815946 / i j s m s-v 4 i 5 p 112}$

Volume: 4 Issue: 5

September to October 2021

https://www.ijsmsjournal.org

is a basic human activity, arising from the need to communicate one's own information, emotions, and thoughts through language. From the first years of life, learners need to focus on teaching how to communicate through gestures, words, facial expressions, and so on. This skill assists the students in expressing their desires correctly, which contributes to their future success in every aspect of life. Second, critical thinking or analytical thinking is a process that involves analysing, evaluating existing information, turning over aspects of the problem to clarify and reaffirm the accuracy of the problem. Critical thinking gives students a general view and the ability to give opinions on many issues, creating positive changes in thinking and action. Recent studies have shown that educators have fully believed that schools should be more focused on teaching students critical thinking. Third, children's brains are many times more creative than adults. It is important for them to have an environment that promotes this ability. Students who are creative and encouraged to promote this are often successful in the fields of society and the arts. Finally, collaboration skills are necessary and important to prepare learners to become workers later on. Good cooperation with others is a prerequisite for students to integrate into any environment, help better work results, promote the development of individuals and organizations. Mentioning the importance of the "Four Cs" for the learners' future success, the American Management Association (2011) confirmed that the "Four Cs" might become even more important to organizations in the future. "Four Cs" would ensure that graders are better prepared to enter the workforce. Besides, emphasizing the importance of teaching the "Four Cs", the findings from the AMA 2010 Critical Skills Survey of American Management Association (2011) indicated that today's students ought to be proficient communicators, creators, critical thinkers, and collaborators (the "Four Cs") if today's students wanted to compete in this fast-changing global society.

This is the gap of Vietnamese education in implementing specific ways to help high school teachers know how to develop the 21st -century learning and innovation skills for students through lesson content. "Four Cs" are recognized by the non-profit educational organization (the Partnership for 21st Century Learning) as important skills that need to be equipped for high school students to form successful citizens in the future. "Four Cs" of the 21st Century skills (communication, collaboration, critical thinking, and creativity) are also part of the four pillars of UNESCO's educational goals-"Learn to know, learn to do, learn to live together and learn to be" to facilitate learners' future success. This must be carried out step by step especially towards English subject. That is why "EFL Teachers' Perceptions of the Significance of "Four Cs" and Their Suggestions to Enhance "Four Cs" for High School EFL Students in Vietnam" was done in this study.

As a response to this dearth of understanding of the topic in the existing literature, the current study examines EFL teachers' perceptions of the significance of "Four Cs" skills for high school EFL students and EFL teachers' suggestions to develop 4Cs skills high school EFL students in Vietnam. In accordance with these two aims, the study seeks to answer two following specific questions.

(1) What are EFL teachers' perceptions of the important role of the "Four Cs" for high school students?

(2) What are EFL teachers' recommendations to enhance the "Four Cs" for high school students?

\section{LITERATURE REVIEW}

\section{A. "Four Cs" as essential skills for EFL students}

1. Definitions of "Four Cs" in education

There are a few definitions for the term "Four Cs". Beetham \& Sharpe (2013) simplified the definition of the 21 st - century learning as an education reform that aims to equip every student with the essential skills to face 21 st-century challenges. The 21st - century learning was introduced in Malaysia in 2014. It emphasized four key elements, which are communication, collaboration, creativity, and critical thinking, also known as the "Four Cs" (AminuddinBaki Institution, 2017). In accordance with the framework of the Partnership for the 21st - Century Learning (as cited in Pardede, 2020), the "Four Cs" were defined as the 21st - century learning and innovation skills necessarily prepared for graders in classroom so that they might obtain future success after high school. The 21st -century learning and innovation skills consist of communication, collaboration, critical thinking and creativity. Michaels et al. (2015) defined each "C" as follows. Firstly, "critical thinking" is the ability to effectively use higher-order thinking skills to plan, teach, and reflect on instructional practice while integrating and applying theories of teaching, learning, and development. Secondly, "creativity" is the ability to develop, choose, and integrate novel, unconventional, and innovative approaches to teaching and learning; Simultaneously, "creativity" is also defined by National Education Association (2010) as the ability to create a new object or concept, or perfect an existing product to make it more attractive. Thirdly, "collaboration" is the ability to work productively and equitably while valuing others in diverse educational settings. Fourthly, "communication" is the ability to successfully use interpersonal skills and components of literacy (reading, 
DOI: $\underline{10.51386 / 25815946 / i j s m s-v 4 i 5 p 112}$

Volume: 4 Issue: 5

September to October 2021

https://www.ijsmsjournal.org

writing, speaking, and listening) to contribute to teaching, learning, and development. Stauffer (2020) expressed some short definitions of the "Four Cs". First, "critical thinking" is the practice of solving problems, among other qualities. Second, "creativity" is the practice of thinking outside the box. Third, "collaboration" was defined as the practice of working together to achieve a common goal. Finally, the art of delivering information rapidly and is known as "communication."

\section{The importance of "Four Cs" for learners' future success}

"Four Cs" (4Cs) contribute to the future success of the learners according to some of the following scholars.

First of all, according to Dung (2020), the $21^{\text {st }}$-century is considered an era of the skill-based economy. Human abilities are evaluated in all 3 aspects of knowledge, skills, and attitudes. Klaus (2010) claimed that only $25 \%$ of successful persons were determined by their professional knowledge while the remaining $75 \%$ were decided by the soft skills they acquired in a proactive, positive manner prior. Therefore, the topic of soft skills training for students is becoming increasingly important in improving the quality of education and training in our country's schools today. In fact, soft skills help first-year students integrate into a good university environment, so high school students need to be equipped with the necessary life skills and soft skills early. This assists students in improving themselves in a positive way, contributing to their future success. Typically, according to employers, soft skills are one of the factors that determine staff recruitment. The ability to adapt, solve problems, communicate and behave in a professional environment are all critical for new university graduates (Dung, 2020).

Emphasizing the importance of the "Four Cs" for the learners' future success, Trilling \& Fadel (2012) (as cited in Roekel, 2017) supposed that in today's digital age, it is more crucial than ever to provide the youth with twenty-first century skills to ensure that the young people can apply these skills to real-world challenges in their job. From Gallup research of Americans aged 18-35, Gallup (2013, p. 4) discovered that after comparing Americans of these ages with a high level of 21st-century skill development to those who did not have enough 21 st-century capabilities, they are twice as likely to have superior job quality.

Trilling \&Fadel (2009) stated that technology's changing natures, global job market competition, and college and career readiness have had an impact on the skills and knowledge that young people are required to succeed in today's global economy.

Potential employees with skills for the modern workforce may be limited. For example, "21st-century skills" is a popular catchphrase for the competencies needed for thriving in a fast-changing and technology-oriented world (Yue-Yi, 2016).Besides, workforce skills and demands were considerably altered in the last 20 years. Many organizations and researchers documented well about the rapid decline in common. At the same time, jobs in regards to nonroutine, analytic, and interactive communication skills increased quickly (Roekel, 2017).

Communication skills are especially critical in the expanding service economy - estimated to be 81 percent of jobs - where relationships with customers and fellow employees are of importance. Effective listening, empathy, and communication skills are crucial abilities for anybody working in the service industry, both linguistically and culturally. (Chiruguru, 2020)

Today's job market requires employees to possess competencies such as critical thinking and the ability to interact with people from many linguistic and cultural backgrounds (cultural competency) (National Education Association, 2017). Levy \& Mundane (2004) remarked that employees in daily work must utilize critical thinking to better serve customers, promote better products, and continuously improve themselves within an ever-changing global economy. These economists have described the new type of work in which the most appealing jobs are those that demand expert thinking and complex communication. Our everchanging workforce creates a critical need for innovation. Kay, CEO of EdLeader21 (as cited in Roekel, 2017) affirmed that critical thinking and problem-solving skills are necessary for today's students, not only used to solve the problems of their current jobs but also employed to meet the challenges of adapting to our constantly changing workforce. According to American Management Association (2011), in the survey of AMA 2010 Critical Skills, after having polled 73.3 percent of business executives, critical thinking was recognized as a priority for employee development, talent management, and succession planning.

Americans perceived creativity and innovation as secondary in our national curriculum before. Today, creativity and innovation are key drivers in the global economy. In today's world of global competition and task automation, innovative capacity and a creative spirit are fast becoming requirements for personal and 
DOI: $\underline{10.51386 / 25815946 / i j s m s-v 4 i 5 p 112}$

Volume: 4 Issue: 5

September to October 2021

https://www.ijsmsjournal.org

professional success. (Roekel, 2017). Besides, when mentioning the role of communication and collaboration skills, Erdoğan (2019) contended that in this global and digital world, communication and collaboration skills enable students to communicate competently and respectfully with others, particularly across cultural lines, in varied and multinational businesses and communities.

To sum up, only people with the knowledge and skills to negotiate constant change and reinvent themselves for new situations will succeed. (Trilling \& Fadel, 2009). In other words, learners accumulating both knowledge and "Four Cs" tend to be successful in the future.

\section{The characteristics and significance of "Four Cs" in academic contexts}

Globalization and digitization have accelerated in the twenty-first century, transforming the way we live, communicate, study, and work. As a result, to succeed in the twenty-first century, graders must possess the socalled "Four Cs" or 4Cs (communication, collaboration, critical thinking, and creativity) in addition to knowledge. EFL classrooms should not only focus on cultivating graders' language skills but also incorporate the "Four Cs" into the learning process to address the obstacles. According to The Partnership for the 21st Century Learning (as cited in Pardede, 2020), "Four Cs" including communication, collaboration, critical thinking, and creativity are regarded as the 21 st - century learning and innovation skills which should be prepared for graders in classroom in order that they can obtain future success after high school. First, critical thinking has been considered a valuable skill in society for ages. Today, every student who is not just an academically advanced learner necessarily has this skill. Whereas critical thinking and problem solving used to be the particular area of gifted students, now it is a critical domain for every student (Roekel, 2017). Conley (2011) ascertained that the relationship between critical thinking and education is apparent: A person cannot learn well without thinking well. Critical thinking not only leads to career success, but also succeeds in higher education. In the research conducted for the Bill and Melinda Gates Foundation, the professor of the University of Oregon, Conley (2011) discovered that "habits of mind" such as "analysis, interpretation, precision, and accuracy, problem-solving, and reasoning" could be as or more crucial than content knowledge in directing success in college courses. Roekel (2017) confirmed that it is important to teach graders critical thinking and problem solving effectively in the classroom. After being taught critical thinking, graders tend to develop other skills such as a higher level of concentration, deeper analytical abilities, and they also improve their thought processing. Today, imperative issues facing global communities are environmental issues (global warming, greenhouse effect, flood, drought, etc.), financial ones, health ones, crime ones, even leisure activities, etc. need to be solved, so the learners need to be well prepared with 'critical thinking' to become active critical thinkers, and certainly, the solutions to international problems require highly developed critical thinking and problemsolving abilities. Second, communication skills also play important role in education. The following skills have traditionally been valued in the workplace and in public life: clearly expressing thoughts, crisply stating opinions, delivering coherent directions, and persuading people through powerful speech (Roekel, 2017). However, in the twenty-first century, these abilities have evolved and are now much more valuable. Because of the strength of modern media and the pervasiveness of communication technologies in all aspects of life, it is even more necessary to develop excellent communication skills.

While fluent reading, proper pronunciation, and clear writing have traditionally been stressed in education, there is evidence that graders are not acquiring these fundamental abilities. Employers remark in the report whether the graders are really ready to work while oral and written communication are two of the top four skills they look for in new workforce, all graduates lack these skills. (Roekel, 2017). According to the final report of The Conference Board of the Partnership for 21st - Century Skills (2011), high school graduates did not meet the requirements of employers; Typically, 72 percent of employers claimed these graduates lacked English writing skills and 81 percent of employers reported that the group of graduates were in a shortage of written communication skills. Nearly half of companies said employees with two-year degrees still lacked these skills, while more than a quarter of firms claimed four-year graduates lacked these skills as well. In reality, communication skills are particularly important in the ever-expanding service economy, accounting for $81 \%$ of jobs by 2014, and relationships with clients and colleagues are crucial. Effective listening, empathy, and communication skills are vital abilities for all people working in the service business, both linguistically and culturally. The economists, Levy \& Murnane (2012) further demonstrated that communication is essential in today's workplace. Complicated communication tasks are unlikely to be automated because they require interpretation, negotiation, and other forms of intense interpersonal contact. While it is important to highlight communication skills, it can be difficult to separate them from other $\mathrm{Cs}$ - especially collaboration. Communication cannot be effective unless the message is received and understood. Third, Roekel (2017) pointed out that various scholars and authors have emphasized the importance of collaboration in education and 
DOI: $\underline{10.51386 / 25815946 / i j s m s-v 4 i 5 p 112}$

career. Collaboration is an indispensable part of our classroom because it is inherent in the nature of the work done in our citizens and working lives. Fifty years ago, people who worked alone did a lot of work, but not today. A lot of meaningful work is done in the team, in many cases, is done in the global team. In general, collaboration has been recognized as a necessary skill for achieving significant and effective results. However, over the past decade, it has become increasingly obvious that collaboration is not only crucial but essential for students and staff, due to globalization and the development of technology. Collaboration has been highlighted by several researchers and authors. For example, Surowiecki (2005) discussed how they leveraged the "wisdom of crowds" in the modern economy by stating that under the appropriate circumstances, groups are incredibly bright, and are often smarter than their smartest members.". Besides, Surowiecki (2005) emphasized the importance of collaboration that a large group of diverse people will make better, stronger forecasts and make even the most skilled decision-makers. Diversity brings many individuals and cultural opinions on cooperation. Collaborative effort not only produces more overall results than individual efforts, but also creates knowledge for more people. Through graders' collaboration, groups could accumulate more knowledge, making collaboration a key factor for student success in today's global communities. The final skill of the "Four Cs" recognized as a necessary one in education is creative thinking. One of the five "minds" the next generation need in the future, according to Gardner (2006), is "the creative mind." He also argued that education is necessarily made up of "exploration, challenging problems, and the tolerance, if not active encouragement, of productive mistakes," to build such a mentality. Creativity plays the same important role in education as in literacy, and we should treat it in the same way (Robinson, 2011) because innovative capability and a creative spirit are quickly becoming essential for personal and professional success in today's global competitiveness and work automation. Previously, Americans considered creativity and innovation as ancillary to their national curriculum. However, today's global economy relies heavily on creativity and innovation. Graders leaving school without perceiving how to develop and innovate regularly will not be adequately equipped for knowledge and skill to solve the problems facing society and the workforce (Roekel, 2017). To sum up, students must learn the necessary skills such as critical thinking, problem-solving, communication, and cooperation for success in today's environment within the context of core knowledge instruction (The Partnership for 21st - Century Skills, 2009).

\section{B. Related Studies}

Some previous researches in terms of the importance of "Four Cs" for learners and with regards to some suggestions of fostering "Four Cs" for high school students were conducted to explore the importance of "Four Cs" for learners' future career, the strategies of preparing "Four Cs" into EFL classroom as well as the researchers' suggestions of fostering "Four Cs" for students.

From the research about "The Essential Skills of 21st - Century Classroom (4Cs), Chiruguru (2020) concluded from his research that critical thinking, creative thinking, 19 collaboration, and communication (4Cs) are among the higher order thinking skills (HOTS) that must be practiced on a regular basis. Graders who were exposed to these "Four Cs" have proven their efficiency by mastering the given content and solving problems.

After the research had been carried out about 'Integrating the 4Cs into EFL Integrated Skills Learning' in 2020, Pardede (2020) presented practical suggestions for integrating the "Four Cs" into integrated skills learning by analysing current thoughts and research findings on integrated skills learning, the benefits of four Cs (the 21 st - century learning and innovation skills), the importance of blended learning in the four Cs, integration of four Cs into language skills and offering practical tips for integrating the "Four Cs" into integrated skills learning.

Halvorsen (2018) focused on bilingualism and biliteracy development. The researcher drew conclusions from many linguistic professionals that learners today need new sets of skills (typically "Four Cs") to prepare them to be successful participants in the globalized society of the future.

Brultey (2015) offered examples of concrete 4C-based school projects that have been experimented with bilingual middle and high school groups of Colegio Columbia, located in Mexico City. These 4C-inspired school projects include the board game design and narrative project, the collaborative writing and roleplaying project, and the open initiative-based project. Ultimately, a series of preliminary conclusions about the usefulness of 4C-based school projects in the hands-on activities and cooperative learning ones can be made in the article. First, these projects allow the EFL teachers to develop a more dynamic student-centered learning experience. Second, as graders are compelled to reach a high level of personal responsibility, they tend to be more engaged. Third, relying on the "Four Cs" brings more flexibility to the teacher, the graders, and the subject itself, breaking the routines associated with traditional schoolwork. 
DOI: $\underline{10.51386 / 25815946 / i j s m s-v 4 i 5 p 112}$

Volume: 4 Issue: 5

September to October 2021

https://www.ijsmsjournal.org

After the research had been carried out about "Integrating 4C Skills of 21st - Century into 4 Language Skills in EFL Classes", Erdoğan, (2019) highlighted the 4C skills in relation to education and proposed linkages with language instruction and their integration into the 4 language skills (reading, writing, listening, and speaking), as well as activities for EFL teachers to develop these skills for their learners.

Albahlal (2019) showed that the 21st - century skills play a significant role for EFL students in their EFL sessions because of the universality of the English language and the necessities of the knowledge-based economy. The study outlined a series of phases or tactics for incorporating 21st-century skills into English language acquisition. Finally, this study's main conclusions were the necessity for significant changes in English language curriculum and teacher awareness.

Handayani (2017) proposed that English teachers should focus on being successful teachers in order to meet the needs of the twenty-first century. Based on the findings of this research, it is critical to shed more light on what matters English teachers should know: 21st - century skills and learning, the features and skills of effective English teachers, the roles of effective English teachers, and many efforts to actualize effective English teachers.

Hernawati (2017) confirmed that a teacher is considered the most significant factor in the 21 st - century educational program because the teachers play such an important role in the teaching and learning process. The world will be lost without a teacher. Unlike the previous era, today's professional teacher should be able to effectively teach and manage a class; build, develop, and manage relationships with graders and the school community; and use technology for more effective communication and education. Therefore, it is crucial to create a comfortable classroom for learners for the 21 st - century teaching.

Roekel (2017) designed a guide that contains ideas and resources to help teachers implement the "Four Cs" in their classrooms. Practical strategies for integrating the "Four Cs" in the classroom, tools for improving technological competency, and ways to ensure that graders are learning in a real setting are all included in these resources. It also includes recommendations on how to get your department, school, district, and state to adopt the "Four Cs."

Sohaya (2020) conducted this research in 2020 at the phase of Coronavirus Disease (COVID-19) pandemic. The article revealed that blended learning and the "Four Cs" are two educational trends that are being used as learning models and fundamental skills to meet the problems of the twenty-first century. Blended learning is a teaching method that mixes face-to-face, offline, and online instruction. Blended learning is a method of introducing and supporting students' digital abilities through the use of technology. Blended learning must equip learners who are both intellectually intelligent and smart in developing personal and social skills including the ability to think critically. As a result, merging Blended Learning and the "Four Cs" into the present learning process is critical in preparing learners to compete internationally and in the future.

Regarding previous studies and available literature in the field of "Four Cs" (4Cs), the EFL teachers' perceptions of the significance of "Four Cs" for learners, and their suggestions to develop these "Cs" skill for learners are of much concern. Among the studies concerning "Four Cs", the participants' recommendations to develop "Four Cs" for learners into specific lessons are still lacking. This gap must be bridged since it can enhance the EFL teachers' pedagogical competencies to promote "Four Cs" for high school students.

\section{RESEARCH METHODOLOGY}

\section{A. Research method}

The research is a descriptive mixed-methods study aiming to examine EFL teachers' perceptions of significance of "Four Cs" (Communication, Collaboration, Critical Thinking and Creativity) for high school students and their suggestions to develop "Four Cs" for high school students. Regarding this, quantitative method under the instruments of questionnaire and interviews were equally employed to effectively address the two research questions in the previous part.The current study used a qualitative research approach, with data gathered through questionnaires and semi-structured interviews with individuals. This qualitative design was chosen because of its ability to allow researchers to dig deeply into the EFL teachers' in-depth grasp of the topic (Corbin \& Strass, 2008).

\section{B. Participants and Research Site}

Fifty EFL teachers from various high school schools in An Giang Province, including 15 males (30\%) and 35 females $(70 \%)$ were invited to respond to the questionnaire. 
DOI: $\underline{10.51386 / 25815946 / \mathrm{ijsms}-\mathrm{v} 4 \mathrm{i} 5 \mathrm{p} 112}$

TABLE 1

SUMMARY OF THE PARTICIPANTS' DEMOGRAPHIC INFORMATION

\begin{tabular}{|c|c|c|c|}
\hline Participants' information & Variables & Number & Percentage \\
\hline \multirow[t]{2}{*}{ Gender } & Male & 15 & $30 \%$ \\
\hline & Female & 35 & $70 \%$ \\
\hline \multirow{4}{*}{$\begin{array}{c}\text { Years of teaching English } \\
\text { (English teaching experiences) }\end{array}$} & Below 1 year & 4 & $8 \%$ \\
\hline & From 1 - 3 years & 1 & $2 \%$ \\
\hline & From 4 - 6 years & 0 & $0 \%$ \\
\hline & More than 10 years & 36 & $72 \%$ \\
\hline \multirow{7}{*}{ Teaching Qualification } & Bachelor of Art in & & \\
\hline & $\begin{array}{c}\text { English (Translation } \\
\text { and Interpretation in } \\
\text { English) }\end{array}$ & 3 & $6 \%$ \\
\hline & $\begin{array}{l}\text { Pedagogical major in } \\
\text { English }\end{array}$ & 43 & $86 \%$ \\
\hline & Master in the & & \\
\hline & $\begin{array}{l}\text { Principles and } \\
\text { Methods in English }\end{array}$ & 4 & $8 \%$ \\
\hline & Language Education & & \\
\hline & Other & 0 & $0 \%$ \\
\hline \multirow[t]{3}{*}{ Educational Institutions } & High school & 36 & $72 \%$ \\
\hline & $\begin{array}{l}\text { High school for the } \\
\text { gifted }\end{array}$ & 11 & $22 \%$ \\
\hline & Other & 3 & $6 \%$ \\
\hline
\end{tabular}

Next, the semi-structured interviews were conducted with the participation of nine high school EFL teachers in high schools in An Giang Province, named as T1, T2, T3, T4, T5, T6, T7, T8 and T9. They include two EFL teachers at a gifted high school and seven English teachers from the high schools in An Giang Province. Among these nine teachers, the eighth EFL teacher (T8) and the ninth EFL teacher (T9) have taught at the same high school for the gifted, and the remaining EFL teachers are the ones at various high schools in An Giang Province in Vietnam. Simultaneously, the eighth EFL teacher (T8) graduated from Master in the Principles and Methods in English Language Education one year ago, and the rest ones belong to Pedagogical major in English.

The participants and the study location mentioned above were because the Covid-19 epidemic has not allowed travel and the author's relationship, she can only invite teachers of some high schools in her hometown of An Giang Province. Regarding this, it was rather difficult to invite similar number of participants from other provinces during this time because the researcher could not contact the participants directly. Accordingly, it was easy and convenient for the researcher to invite the participants by sending a link of the prepared questionnaire to her colleagues who are also EFL teachers in An Giang province, and she also asked these teachers to send the link to other teachers in the same province to participate in this study. Table 2 below showed the EFL teachers' demographic information.

TABLE 2

INFORMATION OF PARTICIPANTS FOR INDIVIDUAL SEMI-STRUCTURED INTERVIEWS

\begin{tabular}{cccccccccc}
\hline Information & T1 & T2 & T3 & T4 & T5 & T6 & T7 & T8 & T9 \\
\hline Gender & $\begin{array}{c}\text { fema } \\
\text { le }\end{array}$ & $\begin{array}{c}\text { femal } \\
\mathrm{e}\end{array}$ & male & $\begin{array}{c}\text { femal } \\
\mathrm{e}\end{array}$ & female & female & female & male & female \\
$\begin{array}{c}\text { Years of teaching English } \\
\text { (English teaching } \\
\text { experiences) }\end{array}$ & 18 & 17 & 7 & 1 & 22 & 16 & 20 & 9 & 14 \\
\hline
\end{tabular}


DOI: $\underline{10.51386 / 25815946 / i j s m s-v 4 i 5 p 112}$

As observed in Table 2, the fourth EFL teacher (T4) was the one that graduated from University two years ago, so she had one year of teaching English, and the remaining teachers had more than 7 years of English teaching experiences. Because of differences in demographic information and the number of English-teaching years, their semi-structured interview data would help the researcher have diverse perspectives from different triangulations for the research theme.

\section{Research Instruments}

\section{1) Questionnaires}

According to Gay et al. (2012) "A questionnaire is efficient; it requires little time and expense and permits collection of data from a large sample". The questionnaire is regarded as an important research instrument because it is a quick, easy, inexpensive powerful evaluation tool. A well-designed and well-used questionnaire can help gather effective and relevant data. 'Primary data' is the data that would exist if it were used for the research process and is collected through both questionnaires or interviews (O'Leary, 2014, as cited in Quad, 2016). In this study, the structured questionnaire was classified into two main sections. The first section with four question items was used toexplore the participants' demographic information including gender, years of teaching English (English teaching experiences), teaching qualification and educational institutions. The second section consists of the fifth question item and the sixth question item that focused on exploring the EFL teachers' perceptions of important role of "four Cs" for high school students and their suggestions to develop "four Cs" for high school students.

Questionnaire was designed in Vietnamese and conducted by EFL teachers in An Giang Province through the link of google form. This questionnaire lasted from 10 to 15 minutes. Before its actual administration, the questionnaire was piloted with $32 \mathrm{EFL}$ high school teachers of various provinces in Vietnam to ensure the reliability of the items in the questionnaire. For this study, the initial step was to collect survey data to check the reliability and validity of this questionnaire instrument. The "Four Cs" questionnaire was meticulously prepared and translated into Vietnamese before being used. Prior to piloting the questionnaire, two competent and experienced professors were requested to provide feedback on their comprehensibility about question items to limit the drawbacks of the instruments. These two specialists' suggestions regarding word choice, format, and grammatical structures were taken into account. Finally, the researcher sent 32 high school EFL teachers in various places in Vietnam the first version of the questionnaire via an online survey on Google Form for piloting phase. The EFL teachers were permitted to use either English or Vietnamese to answer the questionnaires as long as they felt convenient and confident to share the most in-depth information as they could. All of these questionnaires were then transcribed and translated into English and coded by the researcher.

\section{2) Semi-structured interviews}

Semi-structured interview is a qualitative data collecting approach that combines a predefined set of open questions to encourage conversation with the ability for the interviewer to go further into certain themes or replies (Cho et al., 2018). Qualitative research focuses more on interpreting participants' perspectives (Gay et al, 2012). According to Fraenkel et al (2012), interviews are employed to "obtain information that can later be compared and contrasted". If questions are phrased correctly, they will elicit unbiased and truthful responses. In fact, in the questionnaire, the participants were limited to express their perceptions by merely selecting given options, so a qualitative instrument was employed (Quad, 2016).

In this research, face-to-face interviews were carried out with two participants. Besides, interviews were conducted by calling seven participants with Zalo social network for two reasons. Firstly, the Zalo social network is popular and convenient in Vietnam. Secondly, due to the covid outbreak in An Giang Province, some high school EFL teachers couldn't meet the interviewer face to face.

Each interview lasted between 30 to 40 minutes, depending on the interviewee's time. These semi-structured interviews were carried out to answer two research questions: EFL teachers' perceptions of significance of "Four Cs" for high school students and their suggestions about development of "Four Cs" skills for high school students.

After making sure that the reliability and validity of the interview instrument were shown through three pilot semi-structured interviews, the researcher adjusted her own interview questions together with the twoprofessors' counsel and advice. Then, the researcher went on conducting nine officially semi-structured interviews. Each interview for 9 EFL high school teachers was conducted within 30 to 40 minutes and carefully recorded by the researcher with the participants' permission. Next, the Vietnamese verbatim of the interviews was carefully 
DOI: $\underline{10.51386 / 25815946 / \mathrm{ijsms}-\mathrm{v} 4 \mathrm{i} 5 \mathrm{p} 112}$

Volume: 4 Issue: 5

September to October 2021

https://www.ijsmsjournal.org

transcribed. Then, the contents of the Vietnamese transcriptions of the interviewees were analysed into topics and themes relevant to the research aims. Afterwards, the excerpts from the original versions were translated into English by the researcher and sent to respondents for confirmation. Semi-structured interviews including two main questions and sub-questions were employed through one-on-one interviews and telephone interviews to understand more about EFL teachers' perceptions about the essential role of "Four Cs" for high school students and theirsuggestionsto enhance "Four Cs" skills for high school students.

\section{FINDINGS AND DISCUSSION}

The major findings from the study would be discussed in this part in line with the two research questions that the investigation was centered on. Qualitative data collected from the questionnaire were analyzed first, and then qualitative datawere taken from the semi-structured interviews to gain EFL teachers' in-depth understanding of the significance of the $21^{\text {st }}$-century learning and innovation skills (4Cs) for high school students. Concurrently, this part also pointed out several EFL teachers' suggestions to enhance the four Cs skills for high school graders.

\section{A. EFL teachers' perceptions about the important role of "Four Cs" for high school students}

The first aspect which the current study aimed to explore was the EFL teachers' perceptions of the important role of the four Cs skills for high school students.

Evidence from the EFL teachers' responses in the questionnaires clearly revealed that all the participants were highly aware of the crucial role of the $21^{\text {st }}$ century learning and innovation skills (4Cs or "Four Cs") for the future success of the high school students and for intended learning outcome. These participants including Participant 3, Participant 7, Participant 16, Participant 25, Participant 30, Participant 44, Participant 49 pointed out the same viewpoint as below. Take some specific examples from the $16^{\text {th }}$ participant, the $30^{\text {th }}$ participant and the $49^{\text {th }}$ participant as below.

"Learning English together with skills is necessary for students to have good jobs, so it is recommended to equip "Four Cs" for students in high school. The examination must also conform to 4Cs. "[Participant 16]

"In general, all four skills are essential to developing for students, and these skills complement each other."

[Participant 30]

"Four Cs" are extremely required for high school students to integrate into the world later. "[Participant 49]

Compatible with the results gained from the qualitative data above, the findings of the qualitative data of the semi-structured interviews specify that nine EFL teachers were conscious of the important roles of "Four Cs" for high school students. Some examples were illustrated from the following interviewees (T6, T7, and T8).

"Nowadays, I find these 4 skill groups very important for us to learn a certain foreign language well." [T6]

"I realize that "Four Cs" are important. Firstly, students do not learn by rote. Secondly, these skills enable the students to enhance social skills and communication skills. Teachers communicate with the students, and then the class is more active. Because students don't say anything, their class will be boring. So, they have to work together. Likewise, we are learners sitting without saying anything, and we feel bored."[T7]

"I realize that a successful person has both professional knowledge and soft skills, and soft skills are essential for them to go to work later on. Soft skills are crucial to determine our future. Thanks to these, we can find a job and keep it easily. I think these four skills are really vital, so I want to equip students from now on." [T8]

This research was consistent with Albahlal's (2019) titled "The Integration of 21th Century Skills into English Language Learning"), whose finding is about the significant role of the 21th-Century Skills for EFL students. Also, this present research was approximately compatible with Chiruguru's research (2020) titled "The Essential Skills of $21^{\text {st }}$ - Century Classroom (4Cs), whose finding is that critical thinking, creative thinking, collaboration, and communication ("Four Cs") are among the higher-order thinking skills (HOTS) that must be practiced by graders on a regular basis. In other words, "Four Cs" skills play an important role for high school students in the $21^{\text {st }}$ - Century Classroom.

In short, qualitative data from the questionnaire and the interviews showed that most participants (EFL Teachers) had high awareness of the important role of "Four Cs" for high school students. 
DOI: $\underline{10.51386 / 25815946 / \mathrm{ijsms}-\mathrm{v} 4 \mathrm{i} 5 \mathrm{p} 112}$

\section{B. EFL teachers' suggestions for enhancing “Four Cs” skills for high school students}

The second major pedagogical aspect that this study was designed to explore was the EFL teachers' recommendations to foster "Four Cs" skills for high school students. EFL teachers offered eight recommendations to develop "Four Cs" for high school students by means of the qualitative data collection through the semi-structured interview and through questionnaire statistics with open-ended question items.

1. EFL Teachers' Suggestions about Instructional Strategies and Techniques to Develop "Four Cs" for High School Students

\subsection{Instructional Strategies and Techniques to Develop High School Students' Communication Skills}

Qualitative data that were acquired from some interviewees' proposals and collected from the questionnaire statistics revealed some instructional tactics to foster the learners' communication skills as follows:

First, the first interviewee recommended that the EFL teachers have to guide students on how to communicate effectively with others, and some communication skills for learners are instructed from available material. She said, "In speaking lessons, I can guide students on how to communicate effectively. In a new program, there is a lesson of the $12^{\text {th }}$ grade textbook on some communication skills (eye contact)". [T1]

Second, the first interviewee suggested that the final activity of the textbook is essentially converted to a speaking activity. For instance, in addition to the "Speaking" lesson, the final activity of "Reading", "Listening" and "Getting Started", learners should be allowed to speak English with their classmates to increase their communication skills. She described,

"Because according to the current pilot book program, the final activity is converted into a speaking one, which is also a way of integrating communication for students. Teaching all activities in that textbook, the last part is still communication. To my mind, the new general education program, the ultimate purpose is training students skills to apply them in their life, but now in an old general education program, teachers integrate activities themselves somehow to become communication skills. As for the new pilot books now, speaking activity is always available in the end. This is also convenient for EFL teachers." [T1]

Third, the sixth interviewee advised that EFL teachers should give students topics that are practical and familiar to speak and provide them with useful expressions for speaking. Simultaneously, this respondent also suggested that EFL teachers need to create open questions that are appropriate for the student's level especially for weak classes, and these questions should be familiar with the class subject.

“To increase students' communication, I use real situations so that they say the actual work to do. Second, vocabulary must be provided with keywords for them to communicate, or more few words are added from "Speaking" or 'Listening' lesson that will be learnt, and I also elicit some words. For instance, they can speak about what is implied about volunteer work, and they can also present a few relevant instances. Some of them also say something real. They speak in Vietnamese. I help them with English. That is one of the ways they can actively participate." [T6]

Fourth, as for below-average graders, students are necessarily allowed to practice sample dialogues at first and provided prompts of vocabulary and structure for them to do new dialogues, according to the fifth interviewee's narration.

"For communication, in speaking lesson, I ask students to practice sample dialogue on which they are based to speak. Then, I give them cues so that they do new dialogues." [T5]

Fifth, students are permitted to communicate in groups, pairs in activities and encouraged to ask questions. The majority of the questionnaire participants [Participant 3, 16, 19, 17, 30, 31, 33, 37, 39, 48] shared ideas relating to instructional strategies and techniques to develop high school students' communication skills.

“Divide the group to present a topic, let students discuss and argue with each other." [Participant 33]

"Ask students to carry on some activities in groups, including creating a new product based on the lesson." [Participant 48]

"Let high school students interact with each other. Ask students to make a presentation about the topic and other students to ask questions." [Participant 19] 
DOI: $\underline{10.51386 / 25815946 / \mathrm{ijsms}-\mathrm{v} 4 \mathrm{i} 5 \mathrm{p} 112}$

Volume: 4 Issue: 5

September to October 2021

https://www.ijsmsjournal.org

Sixth, EFL teachers should let students switch pairs together, and these pairs are not fixed to be able to develop more communication. Similar to this point, the eighth interviewee reported,

"Students' communication grows through each task. For example, in each activity such as a discussion of the "Getting Started" lesson, under my control, I let them switch pairs together. These unfixed pairs can interact with other pairs to understand other friends better so that they can develop more communication." [T8]

Seventh, it is advised to let students exchange answers with each other and explain the answers they choose. Having this same technique, the seventh participant shared:

“To develop students' communication skills, I let them exchange answers with each other. Teachers need to restrict themselves to saying, but instead, I let them stand up to explain their answer." [T7]

Eighth, EFL teachers should use their encouraging words about the benefits of communication skills to stimulate them to speak. Similar to this, the eighth interviewee and the ninth questionnaire participant provided that:

"In terms of communication skills, I encourage students to say. They cannot develop this skill without talking to anyone. Communication is to help students when they face difficulty, or this problem or that problem, asking friends to help because the one who cannot be good at all fields has to support each other to develop communication."'[T8]

"Call on high school students to support their mutual development." [Participant 9]

Ninth, learners should be allowed to get actively involved in projects by making videos or presentations in the group. The following participants shared ideas relating to instructional strategies and techniques collected from the questionnaire statistics.

"Making videos for projects is to develop English speaking skills." [Participant 25]

"Groups of students give a presentation about their project." [Participant 44]

"Let students make projects." [Participant 49]

Finally, the tenth instructional strategy to develop high school students' communication skills is that as for weak class, EFL teachers ought to make open questions that fit the students' level, and these questions are basically familiar with the lesson content in class. Having the same opinion, the sixth interviewee described,

"Speaking English is often uneasy to students, for example, they can answer questions similar to the lesson.

But, when I ask them open question that is a little different from the lesson, sometimes they do not know how to answer. " [T6]

In brief, Peer Assisted Learning Strategies (PALS) program that has proven to be effective (cooperative learning technique) needs using to incorporate teaching and learning into activities for students to enhance the learners' communication and collaboration. Concurrently, EFL teachers are advised to employ the remaining tips above and pay attention to principles for effective teaching in the $21^{\text {st }}$ - century era. Creating an atmosphere of learning that caters to all learner's skills and abilities.

\subsection{Instructional Strategies and Techniques to Develop High School Students' Critical Thinking}

Some instructional strategies and techniques can promote critical thinking for high school students through qualitative data in the interview and the open-ended section of the questionnaire.

To begin with, the first instructional strategy and technique to promote tertiary students' critical thinking are asking learners to look at problems in new ways and connect what they have learned to the real world. The eighth interviewee explained.

"At the end of the lesson, I'll ask again: I ask the students to repeat these grammatical points, e.g., Passive voice. I want my students to be more creative, for example, today I teach Passive Voice with modal verbs. I only teach them 'can, could, may, might'. I let them talk more about 'had better', 'would rather so that they can develop a more critical mindset." [T8]

"To foster critical thinking and creativity, for example, in the Unit of "Tourism", the question "How can you travel safely?" is asked at the end of the lesson so that the learners can develop their own ideas. "[T8] 


\section{DOI: $\underline{10.51386 / 25815946 / i j s m s-v 4 i 5 p 112}$}

Besides, promoting students' critical thinking at a low level evocative of the song title is considered the second instructional strategy and technique according to the eighth interviewee.

"Critical thinking often has debate. For example, I ask the first student, he or she gives the name to the song. Sometimes, their answer is wrong or right, and other student debate. Frequently listening to the song, there are many students who have critical mindset. Listening to the song is very lively, so there are many students raising their hands. One says this, other says that." [T8]

In addition, the third instructional strategy and technique to foster the learners' critical mindset is allowing them to talk about a certain topic themselves and let other students debate. Similar to this viewpoint, the eighth interviewee and the ninth one described:

"In terms of critical thinking, I allow students to talk about certain topics. For example, teachers show a topic, let students talk about it themselves, and others debate to form students' critical thinking about it." [T8]

"For controversial issues, I ask students a question: "Do you want your mom to go to work or stay at home?". Maybe one group agrees with "I want my mom to be at home to take care of me", but there is another student who wants their mother to go to work and take care of him or her. Such activity is called a dispute. Debating together is based on the topic. It turns out that students do not debate at every lesson." [T9]

Also, other instructional strategy and technique to promote the students' critical mindset in the writing lesson were shared by the ninth interviewee:

"In Writing lesson, EFL teacher gives the students a certain topic, they have to think about it to write down, and argue how to convince others. Critical thinking and creativity are reflected in their composition." [T9]

Moreover, exploring open questions in textbooks to let learners state their own opinions and permit 4 big groups to debate together is an integral instructional strategy and technique to increase the learners' critical thinking. The eighth interviewee stated:

"As for critical thinking, for example, activities related to questions. There are usually 5 questions or 4 questions or 6 questions in the Getting Started lesson. The final question is usually the open one, then I allow my students to state their own opinions. After students at Team 1 present this answer, I encourage students at Team 2 to give another answer so that the groups of four teams in the class debate together. That idea is "acceptable or unacceptable", "Agree or Disagree", "Why" or "Why not" in order that they can develop their critical thinking." [T8]

Furthermore, another instructional strategy and technique to promote students' critical thinking is the projectbased learning approach (PBL). In this case, the students develop their critical thinking during the project with their team. Typically, the $4^{\text {th }}$ interviewee said that when working on the project, students can promote critical thinking even in the average and weak students:

"I think they surely have critical thinking as they can debate with their friends in the process to come up with the best plan and way of doing things." [T4]

When sharing the experience of teaching the project-based learning approach, the $8^{\text {th }}$ interviewee mentioned how to develop the learners' critical thinking at a low level.

“Especially students' critical thinking grows very little when they do homework, because each of them is in charge of doing a small part. When preparing to reassemble each student's small parts, they debate if the work of the whole group is acceptable, but only a few of critical mindset." [T8]

For good students, to promote students' critical mindset by allowing them to make presentations and stimulating them to ask questions and debate with their friends. The eighth interviewee and the ninth participant of the questionnaire survey reported:

"Their critical thinking grows maximum after they present in class, other groups debate. After one group presents, many other groups will ask questions. Maybe they are dissatisfied, they disagree and ask to explain why to select that topic and provide such figures. Instantly, they develop much critical mindset. "[T8] 
DOI: $\underline{10.51386 / 25815946 / \mathrm{ijsms}-\mathrm{v} 4 \mathrm{i} 5 \mathrm{p} 112}$

"Groups of students give a presentation and then other students debate on a topic to come up with their own conception.” [Participant 9]

Finally, some teaching and learning activities to develop high school students' critical thinking from questionnaire instrument include creating questions and asking students, interviewing, discussing, and reporting, asking high school students to comment on their friends' answers or opinions, and organizing English Speaking Contests on topics with Pano Infographics. Some participants who are of the same view above shared,

"Making questions and asking them." [Participant 3]

"Interviewing, discussing and reporting" [Participant 6]

"Discussion" [Participant 39]

“Asking high school students to comment on their friend's answers or opinions." [Participant 17]

"English Speaking Contest about a topic with Pano Infographics" [Participant 25]

To sum up, to equip the learners with critical thinking for their future success, EFL teachers must pay attention to the characteristics of this skill and employ the strategies suitable to each stage, each lesson content based on the graders' ability.

\subsection{Instructional Strategies and Techniques to develop high school students' collaboration skills}

According to the participants' suggestions, there are three instructional strategies and techniques to develop high school students' collaboration skills.

First of all, EFL teachers should have students working together before they stand up to present in front of class. Mentioning this instructional strategy, the seventh interviewee and the ninth one shared:

“...Before the students stand up to speak, they team up with their classmates, whom they sit next to or opposite, then they explain to the class." [T7]

"I see that the most common activity is talking together in groups and pairs to develop communication skills. '”T9]

Second, it is an indispensable strategy for EFL teachers to allow students to work in pairs, in a group with alternate changes to avoid boredom. Supporting this view, the seventh interviewee said:

"The first thing is through pair work and groupwork. However, to reduce the students' boredom, we need to make alternate changes instead of working in pairs that are always traditional and boring." [T7]

Similarly, when talking about collaboration, the eighth interviewee shared his teaching experience in integrating this skill in his EFL classroom:

"First, to develop collaboration skills for students, at the first lesson of English textbook, for example, the first activity is working in pair, the second activity is working in a group of four. For the discussion, in the end, I also have them working in large groups of about 6 to 8 persons to let them get used to the way of mutual learning cooperation so that they know how to cooperate in other things as well." [T8]

Having the same idea, the ninth questionnaire participant mentioned:

"Ask students to work in pairs and in the group." [Participant 9]

Last but not least, other strategies and techniques collected from the open-ended questions of questionnaire consist of interaction in Zalo group, carrying out the collective game, using lively visual aids to promote the learners' collaboration.

"Carry out Zalo group while studying together." [Participant 25]

"Use lively visual aids." [Participant 37]

"Always use games in warm-up activities." [Participant 44]

By and large, pair work, groupwork so-called Peer Assisted Learning Strategies (PALS) or cooperative learning approach are the ways of classroom interaction to promote high school students' collaboration. 
DOI: $\underline{10.51386 / 25815946 / \mathrm{ijsms}-\mathrm{v} 4 \mathrm{i} 5 \mathrm{p} 112}$

\subsection{Instructional Strategies and Techniques to Develop High School Students' Creative Skills}

To develop high school students' creativity, participants suggested some instructional strategies and techniques as follows:

First of all, students can promote their creative skills by means of the Project-Based Learning approach (PBL). Agreeing with this point of view, the $6^{\text {th }}$ participant and the $44^{\text {th }}$ participant that got involved in the questionnaire survey shared another idea to increase the learners' creativity.

"Project." [Participant 6]

“Allow students to present the project by making video clips, etc.” [Participant 44]

PBL has typical activities such as making video clips, drawing, telling real-life stories, etc. In this case, the 7th interviewee allowed students to choose random papers on the topic of project work from the beginning of the year, students worked in groups to prepare for the project in advance to present to the class.

"I let them get engaged in Project-Based Learning related to certain topics. They also had creativity through finding out video clips regarding that topic, and they presented in advance in the class hour of "Getting Started" lesson." (...) "For example, I asked the students for proof of the work they had done before studying this lesson. It means they recount a story or draw a picture if they can. I also give marks to them if they draw the right subject. If they are able to draw, they will find a video, and then they will show the video in front of the class, for example, the video about volunteer work. Such project work is also a form of creativity." [T7]

Besides, the learners' creativity will be boosted in case of reducing the content load for a project to fit their ability, especially the class with students' weak levels. Like this view, the third interviewee and the seventh interviewee pointed out that:

"I can reduce content load instead of using the instruction in the textbook. I select more suitable content. For example, in terms of 'Ecotourism', I have recently chosen to let them design posters promoting ecotourism, which is more suitable. They are allowed to choose content and destination themselves, which makes them more excited, promotes their creativity and motivation to get engaged more actively."[T3]

"I expect weak students to be creative as long as they speak realistically or imagine what volunteer work, they have liked and done. That is precious." [T7]

In addition, asking students to prepare their lessons in advance at home is another idea for boosting students' creativity, particularly mediocre students, because most mediocre students struggle to keep up with EFL teachers' teaching speed and assignment requirements. This is the view that was shared by the second interviewee.

"I discover creativity in "Speaking" lesson, e.g. I ask students to prepare a topic at home first. Then, I let them make the presentation. I have recently let the 11th graders talk about 'conflict between parents and children' and how to resolve it. Typically, talking about 'volunteer works', the tenth graders had creativity." [T2]

Similarly, the $16^{\text {th }}$ participant and the $37^{\text {th }}$ participant also had the same opinion above that was collected from the questionnaire statistics:

"Ask students to research new lessons before class" [Participant 16]

“Enhance self-study exercises at home." [Participant 37]

Also, there can be no doubt that brainstorming activity, a technique familiar to most EFL teachers, enables students to develop their creativity. The $7^{\text {th }}$ interviewee and $9^{\text {th }}$ interviewee shared:

"As for critical thinking and creativity, I advise teachers before teaching any skill. First, students" brainstorming is regarded as a must. i.e., they think of an idea for that topic. Next, I gather more ideas for the whole class, which makes them understand more and develop more ideas." [T7] 


\section{DOI: $\underline{10.51386 / 25815946 / i j s m s-v 4 i 5 p 112}$}

"In writing lesson, I carry out each step of Pre-While-Post activities. I often use Communicative Approach, warm-up activity, Pre-writing one to teach students' ideas and structures. In the Pre-Writing one, I have to brainstorm some ideas for them to write."[T9]

Moreover, allowing the students of the good class to imagine writing emails is a technique to enhance their creativity in the "Language and Pronunciation" class. For a good class, the $7^{\text {th }}$ interviewee talked about how to integrate creativity into 'Language and Pronunciation'. Typically, the $7^{\text {th }}$ interviewee promoted the learners' creativity in this class by permitting them to imagine writing emails to someone, reusing the vocabulary or grammatical points that they have learned.

"As for a quite good class, creativity is possibly boosted in this lesson. I let them take advantage of review content. I let them imagine writing an email to someone, reuse the vocabulary or grammar points that they have learned. For example, my assignment is 'Imagine a friend, imagine a problem that you used to tell, using the grammar points learned'. That is also a form of promoting creativity." [T7]

Furthermore, using open-ended questions outside the textbook is also a technique to increase the learners' creativity. Ideas of the open-ended question item that were collected from questionnaire survey show this viewpoint of the $3^{\text {rd }}$ participant and that of the $26^{\text {th }}$ participant, "Making questions" [Participant 3, Participant 26]

In terms of the experiences of integrating creative skills into the "Getting Started" lesson, open-ended questions are related to creativity, so the 8th interviewee described as follows:

"There are open-ended questions as regards creativity. After I had taught vocabulary in the "Getting

Started" lesson, which includes open-ended questions, I gave open questions in terms of the environment instead of asking them to practice speaking in the textbook. For instance, what solutions do you share to protect the environment in your surroundings? Such open questions which are not tied to textbooks help the learners develop their creativity." [T8]

What's more, recall and inference activities are regarded the suggestions of the $7^{\text {th }}$ interviewee to enhancing students' creativity.

"Post-reading activity is based on the students' competence. For the weak class, I ask them to recall with word cues. If EFL teachers want to promote moderate creativity, they must do that. For good classes, sometimes recall or inference is used. I think the inference is the best. The inference is also considered a good stage for learners to be creative. As for a good class, students are given more sentences to recall lesson information requiring them to rewrite the sentence." [T7]

Finally, another technique collected from the questionnaire to develop high school students' Creativity belongs to the $25^{\text {th }}$ participant's viewpoint. This teacher shared:

"Show students online videos illustrating lessons"(Participant 25, Questionnaire)

Mentioning the role of creativity, Roekel (2017) stated that today's global economy is strongly reliant on creativity and innovation. Students who leave school without understanding how to develop and innovate on a regular basis will lack the information and skills necessary to solve the difficulties that society and the workforce face. (Roekel, 2017).

In general, to develop the graders' creative skills, teachers not only apply instructional strategies but also give students chances to do project activities and exercise requirements suitable for their abilities, especially weak classes. Concurrently, teachers are required to flexibly adjust teaching activities depending on the interests or the trends of the youth today when integrating this skill into the sessions. 
DOI: $\underline{10.51386 / 25815946 / i j s m s-v 4 i 5 p 112}$

Volume: 4 Issue: $5 \quad$ September to October $2021 \quad$ https://www.ijsmsjournal.org

\section{EFL Teachers' Suggestions about Integrating "Four Cs" into EFL classroom through Hands-on Activities}

Through some interviewees' narration and through ideas from the open-ended questions of the questionnaire statistics, qualitative data pointed out the features of "Four Cs" and ways to integrate these skills into hands-on activities.

First of all, in the opinion of the $8^{\text {th }}$ interviewer, the reason why "Four Cs" are officially taught in class and only integrated into class instead is that the time to teach knowledge is too much, so the teacher can only integrate them into the lesson through workgroup or pair work activities, which obviously promotes the learners' collaboration and communication skills. This interviewee narrated,

"I care "Four Cs", but the time to teach knowledge is too much, so I only integrate them into the lesson. This means that groupwork and pair work activities let them work together, then I also encourage them to state their own opinions and develop their communication skills with their friends. Instead of teaching "Four Cs" all the time, through those activities, I only apply "Four Cs" like that." [T8]

Like the view above, the $25^{\text {th }}$ questionnaire participant claimed:

"4Cs should be integrated into empirical activities." [Participant 25]

Second, the characteristics of the teaching approach of "Four Cs" skills are evidenced by the eighth interviewee's recounting of his prior professor's teachings. The new teaching approach is distinguished from the traditional teaching method by the integration of "Four Cs" skills: Firstly, teachers do not speak much. Secondly, in the classroom, teachers assist learners in developing their 'Cs' skills.

"The trainer said that the class process is different than before. It means that the teachers must not talk much, but they let the students speak, communicate with their classmates, communicate with the teacher. The learners have to cooperate, work in groups and in pairs so that they will develop skills, and then they must be creative rather than only sitting passively. They have to receive knowledge and react to it actively. " [T8]

The $9^{\text {th }}$ interviewee also had the same view as the $8^{\text {th }}$ interviewee:

"I think teachers need to integrate these 4 skills into the lecture, but I integrate these 4 skills in the same way as teaching knowledge. Through tasks, activities, and exercises given to students, knowledge is transmitted to students, and their skills are also developed."

Third, according to the $2^{\text {nd }}$ interviewee, the $8^{\text {th }}$ respondent and the $9^{\text {th }}$ respondent, the integration of "Four Cs" for learners at an early stage, is one of the issues faced by EFL teachers. Investing time in gathering materials, learning activities, finding teaching resources, and preparing lesson plans to both impart knowledge and integrate these skills into the lesson are some of the teachers' challenges. The teachers have some difficulties at least initially, but they gradually become accustomed to combining the four 'Cs.' To overcome the challenges of the initial phase of teaching the four 'Cs,' teachers must be patient and practice these abilities throughout the school year. The 8 th interviewee, the $9^{\text {th }}$ interviewee and the $2^{\text {nd }}$ interviewee are of the same opinion above. For example, the eighth interviewee described as follows:

"At first, it is hard because we are not used to, e.g., having to divide groups, having to manage too many activities to let them cooperate, communicate with their classmates. The class is sometimes noisy, but then teachers and students gradually get used to these activities, slowly go into the routine, I feel easier." [T8]

Fourth, there are two elements that stand out in the process of combining these four skills in English class. When incorporating "Four Cs" skills, according to the third interviewee and the eighth interviewee, the first noticeable thing is adjusting lesson content appropriately. Many skills cannot be integrated into a single lesson. The teachers will choose appropriate skills based on the content of the session for the learners to develop. The second notable feature is the flexible integration of "Four Cs" based on the competence of each class. On the report of the first interviewee, the fifth interviewee, and the sixth respondent, this is primarily due to the difficulty of merging critical mindset and creativity into classes, which is dependent on the students' competency and the EFL teachers' time allotment in class. As a result, creativity and critical thinking are reserved for bright students while communication and teamwork skills are reserved for mediocre students. In other words, teachers face difficulties in time and student level in a class with average students. Thus, teachers must be able to adjust textbook-based lesson content in order to retain the content and integrate skills appropriate for their own class level. Not all "Four Cs" skills are necessarily integrated in the same lesson. 


\section{DOI: $\underline{10.51386 / 25815946 / i j s m s-v 4 i 5 p 112}$}

Fifth, in addition to characteristics of the teaching approach of "Four Cs" skills, the $7^{\text {th }}$ interviewee discovered that it is straightforward for EFL teachers to promote their students' communication and collaboration skills by engaging them in cooperative activities while maintaining careful class control.

"EFL teachers today have really had these four skills. My suggestion is that in order to enhance communication and collaboration, graders are asked to work in pairs, but pair work is perfunctory, so we have to stimulate them so that they will see our care, and then they will get involved in communication more actively." [T7]

Sixth, this $7^{\text {th }}$ interviewee also found out that brainstorming is an instructional technique allowing graders to promote their critical thinking and creativity.

"As for critical thinking and creativity, I advise teachers before teaching any skill. First, students' brainstorming is regarded as a must. i.e., they think of an idea for that topic. Next, I gather more ideas for the whole class, which makes them understand more and develop more ideas. Then I will also gather vocabulary, and I always ask more questions related to their thoughts about that topic. So, I think any skill can be done like that." [T7]

Seventh, scaffolding is another educational approach for improving learners' skills and assisting them in completing tasks more quickly, according to the $8^{\text {th }}$ interviewee.Scaffoldingis also an instructional technique todevelop the learners' skills and help them accomplish the tasks easily. According to Wikipedia, scaffolding has some benefits as follows:

"It promotes the students own cognitive, affective and psychomotor learning skills and knowledge." Wikipedia

According to the article, "12 Scaffolding Techniques to Implement Now" written by Caitriona Maria on October 25, 2020, in education, scaffolding refers to using a number of teaching strategies to guide graders toward deeper comprehension. Scaffolding aids graders who lack the resources and skills necessary to complete the task on their own. Scaffolding with a variety of advantages assists the learners in becoming problem solvers and motivates them to complete their assignments. It provides graders with the tools and resources they necessarily improve their skills and accomplish the task. According to the article of Caitriona Maria, there are 12 scaffolding techniques: (1) Tap into Background Knowledge, (2) Model by the teachers or students, (3) Guided Practice, (4) Use Prompts, (5) Give Hints, (6) Describe Concepts in Different Ways, (7) Think Aloud, (8) Read Aloud or Text to Speech, (9) Strategy Instructions, (10) Use a Graphic Organizer (A graphic organizer, such as a mind map or story map, organizes information in a way that is easier for students to remember), (11) Pre-Teach Vocabulary and (12) Scaffolding Questions (used to make sure students understand what they learn and challenge them).

In this research, some of those Scaffolding techniques that were suggested by some interviewees are tapping into background knowledge, using prompts, giving hints, prediction and scaffolding questions. The $7^{\text {th }}$ interviewee shared the first feature of scaffolding through using prompts:

"For example, in terms of recalling vocabulary, there are many ways depending on lesson content typically giving questions. I almost like to show some keywords about something, and then when they look at those keywords, they will recall the whole sentence which is possibly remembered in the lesson or the sentence has both the subject, verb and object. But if it doesn't work, it makes sense. I elicited the keywords by giving a verb to the good class while I gave verbs and some adverbs to the weak class." [T7]

The second characteristics of scaffolding is about the way to teach through giving hints and through tapping into Background Knowledge, which was described by the $8^{\text {th }}$ interviewee.

“Kimono is a symbol of Japan. I'll ask, 'Do you know Kimono?' Students will reply, 'Japanese tradition'. I'll ask, 'When do Japanese usually wear it? What does it mean?' To develop their speech, I usually do the first activity: I show the pictures or I give a column with about 4 phrases. The other side is empty to let them develop their ideas to speak, and I lead into a new lesson.'[T8]

The third feature of scaffolding approach is stimulating students' creative thinking and critical thinking. According to the $7^{\text {th }}$ interviewee's description, she applied the instructional technique of scaffolding prediction into her EFL class. 


\section{DOI: $10.51386 / 25815946 / \mathrm{ijsms}-\mathrm{v} 4 \mathrm{i} 5 \mathrm{p} 112$}

"I integrated critical thinking into my lesson. I let my graders think. For example, simply before they listened, I let them predict True or False statements. They guessed True or False statements based on content and logic, which is called the instructional technique of critical thinking. Students with critical thinking certainly will be creative. I think those two skills supporting each other are not separate. The only thing is which one between these skills is clearer by any way." [T7]

Similarly, the $5^{\text {th }}$ interviewee shared her own teaching process in class with regard to scaffolding prediction although she was unaware of the significance of this strategy contributing to the development of skills for the graders.

“Going to class, I always have warm-up activities, bingo or Kim's Game to lead to new lessons. There will be illustrative examples to introduce grammatical points. Teaching "Reading” lesson, I show a picture to the whole class to see and guess the topic." [T5]

Eighthly, the combination of scaffolding questions and brainstorming is a perfect strategy to promote the "Four Cs" skills of the graders. Like this view, the $7^{\text {th }}$ interviewee described as follows:

"For Reading, I think question shows all four skills. For example, I first let the students brainstorm the topic through the question. When they brainstorm the topic, they use their critical thinking. In the process of working collaboratively, they share the ideas, they also collaborate and communicate with each other."

Ninthly, from the descriptions of the $2^{\text {nd }}$ respondent and the $8^{\text {th }}$ interviewee, motivation is considered an approach for developing learners' "Four Cs" skills, and extrinsic motivation often comprises rewards, grades, compliments, and so on. With the same viewpoint, the $8^{\text {th }}$ interviewee described the way that he developed "Four Cs" skills for his graders through score incentives:

"In addition, I also encourage my learners by giving marks and commending them. For example, if they argue well, I give them marks. They cooperate well, and I also give them marks."[T8]

"Yes. I score their 15-minute test column for their speaking speech or add a score for them."

According to Richard (2018), one of eight ideas for building intrinsic motivation is "Use grades to communicate levels of learning, from the beginning to the end."

Tenth, preparing lesson plans at home carefully and making more investments in class are the third interviewee's advice and the eighth respondent's suggestion to boost the graders' intrinsic and extrinsic motivation and develop their skills. In order words, careful lesson preparation at home helps teachers hold the initiative in the classroom all the time, which stimulates the learners' spirit to both accumulate knowledge and improve skills for them.

"These 4 skills are very important. I advise teachers to prepare lesson plans carefully before coming to class due to the very limited time while we try to integrate these skills into each activity for graders, as a step to prepare them to go to university to access higher education environment more easily." [T8]

"For the remaining lessons, I see some more things to share. If it can be done, that is fine. Each teacher themselves must carefully study that lesson, redesign, for example, what skills the teacher wants to develop for the graders, he or she redesigns the activities accordingly based on the instructional activities in the textbook. Redesigning is to promote that skill. $100 \%$ of the available content in the textbook should not be taken. Depending on the purpose of each teacher, achieving the purpose of our lesson is acceptable after that lesson.", and (...) "Yes, That's right. Adapting. "[T3]

Eleventh, blended learning and the "Four Cs" are two educational trends in the current era of digitalization. Nowadays, most teachers and students in Vietnam use the Internet and mobile phones for their teaching and learning processes. As for the students in Vietnam, using the Zalo social network for their learning is popular, so the $25^{\text {th }}$ participant suggested in terms of technique to promote the learners' collaboration.

“Carry out Zalo group while studying together." [Participant 25]

Besides, Blended Learning has another benefit in solving mutual problems of the learners. Collaboration and teamwork have always been necessary when solving problems. On the other side, open-source software, wikis, 
DOI: $\underline{10.51386 / 25815946 / 1 j s m s-v 4 i 5 p 112}$

blogs, and other Web 2.0 technologies allow total strangers separated by distance and time to engage. Successful problem solving in the twenty-first century demands working effectively and creatively with technology, enormous amounts of data, confusing situations, and people from varied backgrounds. (Roekel, 2017)

Last but not least, one of the most important approaches for bringing the 4 Cs into an EFL classroom is the project-based learning approach (PBL) which has hands-on activities to promote $4 \mathrm{Cs}$ for learners. According to some interviewees (T1, T 3, T4, T8, T9), PBL promotes many skills for learners, especially the $21^{\text {st }}$ - century skills. Having the same opinion about the benefits of PBL towards the learners, in the article entitled ' 10 Benefits of Project-Based Learning', Shaffer (2018) stated that Project-based learning (PBL) is a dynamic instructional method that provides students with numerous benefits, ranging from critical thinking to project management to self-confidence. Similarly, Motallebzadeh, Ahmadi and Hosseinnia (2018) [as cited from Şahin\& Han (2020)] confirmed that Project-based instruction, communication, teamwork, critical thinking, and decision making have a substantial impact on EFL learners' $21^{\text {st }}$ - century skills in ELT classrooms.

To sum up, knowing the features of integration of "Four Cs" together the previously-mentioned instructional strategies as well as techniques, the English teachers will be able to create an active learning environment, which stimulates the graders' 21 st- century skills, particularly the "Four Cs" of learning and innovation skills, including critical thinking, communication, collaboration, and creativity.

\section{EFL Teachers' Suggestions about Integration of "Four Cs" into each specific lesson}

In this research, nine interviewees frankly shared their teaching experiences in connecting ideas with "Four Cs" although these four skills have not been officially applied in high schools in An Giang Province as well as other high schools in Vietnam. Each specific lesson that these interviewees described is related to the old sevenyear textbooks and the new ten-year textbooks, both of which stand for the old general education program and the new general education program. Each unit of the seven-year English textbooks includes "Reading" lesson, "Speaking" lesson, "Listening" lesson, "Writing" lesson and "Language Focus" whereas that of the ten-year English textbooks consists of "Getting Started", "Language and Pronunciation", "Reading" lesson, "Speaking" lesson, "Listening" lesson, "Writing" lesson and "Looking Back and Project".

In the descriptions of the interviewees, all their teaching steps follow the Pre-While-Post steps, which features the EFL teaching method. Their task-based instruction and communicative approach contribute to the development of "Four Cs" for the learners. They also used brainstorming and scaffolding techniques, which help the students promote their "Four Cs" skills. However, some of the interviewees were not aware of the benefits of these techniques associated with the development of "Four Cs" for the learners, so their teaching activities in class were perfunctory. If a large number of English teachers know the characteristics of "Four Cs" skills and the strategies above, they can make students increase these four skills.

Besides, among the Pre-While-Post steps, there were participants using the review step at the end of the lesson. This step allows the learners to foster their critical thinking. This opinion was consistent with Roekel's viewpoint (NEA, 2017), i.e., teachers invite students to reflect the information obtained in the classroom at the final stage of the lesson through three steps: (1) asking the learners to discuss the material taught at the end of the class (what do we learn today?); (2) asking them to give messages and impressions when attending class; (3) interpreting information and drawing conclusions;

Above all, if a significant number of English teachers are familiar with the features of the four "Cs" skills as well as the tactics listed above, they can help students improve their four "Cs" skills successfully.

\section{EFL Teachers' Suggestions about Curriculum Development with "Four Cs"}

In terms of the online questionnaire participant's suggestions, it is exciting to explore that curriculum development is also considered as a recommendation to development of "Four Cs" for high school students. With regards to this suggestion, the ninth online participant contended:

"Hopefully, in the future, MOET will consider distributing the lessons with the appropriate duration so that there is a certain period of time to integrate these skills into EFL classrooms to develop students' skills." [Participant 9] 
DOI: $\underline{10.51386 / 25815946 / \mathrm{ijsms}-\mathrm{v} 4 \mathrm{i} 5 \mathrm{p} 112}$

Volume: 4 Issue: 5

September to October 2021

https://www.ijsmsjournal.org

According to Rotherham and Willingham (2010), it will be superficial for long-term gains if $21^{\text {st }}$-century skills are not combined with curriculum, teaching, and testing corresponding to them. Therefore, governments, higher education institutions, and educators in both pre- and in-service education are all responsible in some way.

Above all, much work remains to be done to address these difficulties by incorporating 21 st-century learning standards and developing curriculum that teaches to those standards. Graders and instructors must learn and share knowledge in the $21^{\text {st }}$ - century context (Hernawati, 2017).

\section{EFL Teachers' Suggestions about Professional Development with "Four Cs"}

\subsection{The Need for Intensive Training of "Four Cs" for Teachers}

From the descriptions of the $2^{\text {nd }}$ respondent, the $3^{\text {rd }}$ respondent, the $4^{\text {th }}$ interviewee and the $6^{\text {th }}$ interviewee, the challenges were faced by these participants owing to teaching classes with many mediocre graders, due to the fact that teachers have not been trained in the method of integrating "Four Cs", since the new textbooks challenge teachers and because the Ministry of Education and Training of Vietnam has not issued a document requiring teachers to integrate "Four $\mathrm{Cs}$ " instead of focusing only on 4 language skills and focusing on graduation exams for the $12^{\text {th }}$ graders.

"I find it difficult, too. First, I do not have many methods to develop these 4 skills for graders. Second, the graders' weak level and their abilities make teachers unable to perform their teaching activities well.I think after the students are slowly instructed from easy to difficult activities, they will get used tothose activities."[T2]

"Firstly, this is a new set of textbooks, so the EFL teachers themselves have not much experience in teaching selective content. Even the professional team have not had discussions to research lessons yet, so it leads to such difficulties.", and "Most teachers have not been trained, so they apply "Four Cs" skills asynchronously. Each person has an idea, and each person has a way."[T3]

"Although I want to improve soft skills for myself and for my graders, I feel that they are not easy because the distribution of grader level is uneven in a classroom. There are quite good graders, and there are students who are not as desired, then I integrate those skills into EFL class, there are those who have not kept up with me, especially good students who can." [T4]

"In class, I think I can do these skills, but the level of performance is not intensive. It implies that when I carry out it, the students' vocabulary is too weak, which does not meet my requirement of activity. Some questions that lead to a new lesson. The question is rather challenging for example "what do you think ...?" My students speak one to two words. They do not speak a long sentence or a long idea, so I cannot implement the next idea to communicate with my learners. "[T6]

Accordingly, their expectation will be the need for intensive training of "Four Cs" for English teachers in case the document is issued by the MOET of Vietnam to force the EFL teachers to combine "Four Cs" into EFL class.

"If possible, the seminars are organized much more, and the other lessons are spent more time and deeper instead of just focusing on one content."

"...I also want to have seminars with professional instructors teaching the high school teachers the methods of critical thinking and creative skills which will be applied to teach graders in the EFL classroom." [T2]

"Critical thinking is the most difficult of the four skills. I don't think teachers keep teaching this skill, and graders will grasp it, even the teachers themselves. It's not that learner will learn this skill, but I think it depends on the way, savvy, and ability to analyse and evaluate each person's matter. So, I think that a training process is required to develop this skill for the learners instead of a short time of one day or two days, vice versa, this cannot be done.", and (...) "Teachers need to take the course to be trained by a specialist about this skill for graders." [T4] 
DOI: $\underline{10.51386 / 25815946 / i j s m s-v 4 i 5 p 112}$

Volume: 4 Issue: 5

September to October 2021

https://www.ijsmsjournal.org

This is compatible with Handayani's viewpoint (2017) that competence is the most important factor in achieving teacher professionalism. Therefore, it is necessary to build a team of competent teachers for effective teaching in class. Likewise, Hernawati (2017) pointed out that because English teachers play such a crucial role in the teaching and learning process, they are regarded as the most important factor in a 21 st-century educational program. Without a teacher, the world would be lost. Today's professional teacher must have the ability to efficiently teach and manage a class. They must establish, maintain, and manage connections with students and other members of the school system. They should employ technology right away to improve communication and education. As a result, in order to educate in the twenty-first century, it is critical to creating a welcoming environment for students.

\subsection{The efforts of the EFL teachers need to be made}

Through the semi-structured interviews, the qualitative data reached some suggestions from the interviewees. First of all, If the Ministry of Education and Training of Vietnam requires EFL teachers to integrate these four abilities into their EFL classrooms, they must make great efforts. The $37^{\text {th }}$ participant and the fourth interviewee had the same opinion as this suggestion. Second, according to the fifth interviewee, in case there is no training course trained by language experts, teachers necessarily learn more themselves to promote "Four Cs" skills for graders, they need to invest their efforts and time in their lesson plans, apply suitable activities for these skills and try integrating these skills in the first few lessons in a semester, learn mutual experience from group meetings of the English teachers.

\subsection{The necessity of professional workshops and the meetings of foreign language groups}

There are some suggestions about the necessity of professional workshops and the meetings of foreign language groups.

First, it is necessary to organize the professional workshops and meetings of foreign language groups to promote studying how to integrate these "Four Cs" for graders.

Second, mutual cooperation among English teachers in the foreign language group is to build the curriculum and professional development on the basis of integrating "Four Cs" in lesson research in order to promote "Four Cs" for high school students.

Third, it is critical to have mutual support from the foreign language group's teachers in exchanging experiences in merging the "four Cs" skills. The foreign language group should schedule time to study lessons at school once every two weeks for each skill, from 15 to 20 minutes, to share how to merge skills into English class.

Fourth, interestingly, the eighth interviewee supports teacher meetings for the foreign language group at school, whereas the ninth interviewee supports large-scale teacher meetings or seminars for teachers from many other high schools. Each teacher who also has to have their own expertise has been taught to know what these four skills are and the tactics used to incorporate them into the class so that they can learn from each other's experiences. A specific researcher or a training instructor passes these ideas on to high school EFL teachers. They then use those tactics to teach a lesson in class, which is seen to be more effective. Then, in order for these teachers to learn from one another, seminars or group discussions are held. Using this strategy not only saves time, but it also produces the desired result.

Consistent with these suggestions, Brown (2001) [cited from Handayani (2017)] pointed out that English teachers can attend some conferences and workshops to gain more insight into their subject.

Identically, according to Donaldson et al. (2013) [cited from Handayani (2017)], professionalism, competence in using educational technology, especially ICT, pedagogical competence, organizational competences and teamwork abilities, openness and flexibility are all factors to consider programs for initial teacher training. Finally, English teachers must always foster their pedagogical competence and professional qualifications at a higher level for effective teaching in class.

To summarize, if the Ministry of Education and Training requires EFL teachers to integrate these four skills, each teacher must put forth a significant amount of effort and rely on the mutual support of the foreign language group's teachers to schedule time for study lessons at school or professional workshops sponsored by the Department of Education and Training of An Giang Province. 
DOI: $\underline{10.51386 / 25815946 / i j s m s-v 4 i 5 p 112}$

\section{EFL Teachers' Suggestions about Assessment in Learning and Teaching to develop "Four Cs"}

In the opinion of the fifth interviewee, the format of the national high school exam's test paper is geared towards reading and writing skills. In other words, students just need to be able to read and write in order to pass the ministry's national high school exam. From her own point of view, it is not necessary for high school graders to have these four skills.

"In the format of the ministry's national high school exam, students only need to include reading and writing skills. These 4 skills are only suitable for students at colleges and universities, high school students do not necessarily have these 4 skills." [T5]

Accordingly, if "Four Cs" skills are included in official teaching, then the format of all examinations must also be altered synchronously according to the standards of these "Four Cs" skills. It means that the student's academic performance must also be assessed according to the standards of "Four Cs" skills. In the same view, Participant 16 has the following comments: "Learning English together with skills is necessary for students to have good jobs, so it is recommended to equip "Four Cs" for students in high school. The examination must also conform to 4 Cs."

In other words, if the four "Cs" skills are included in formal teaching, the format of all assessments must be altered to reflect the four "Cs" skills' criteria. Synchronization helps learners be more productive in this way.

Previously, Bloom (1956) stated that the teacher uses questions to assess graders. Next, the teacher assesses, identifies, summarizes, and justifies the ideas given by students, comparing and contrasting them.

Nowadays, in the $21^{\text {st }}$ - century skill era, if teachers employ four Cs skills into English class, they also must apply measures of assessments compatible with the four "Cs" skills' criteria, especially conformable to the assessment framework of the Partnership for the $21^{\text {st }}$ - century mentioned in the Literature Review.

\section{EFL Teachers' Suggestions of Setting up a Learning Environment to Increase Experiential}

\section{Effectiveness}

The semi-structured interviewees made the following suggestions regarding creating a Learning Environment linked to the "Four Cs" skills to improve the graders' experiential effectiveness. First, rather than skipping this assignment, the PBL Approach should be applied to extracurricular activities that are regarded appropriate. Second, extracurricular activities, typically in English-Speaking Club, help in developing communication skills, creative skills for students. Third, it is interesting to collect the third interviewee's idea. That is although guiding students to do scientific and technical research projects does not have much to do with expertise, he supposed that this is a very interesting activity that also makes an important contribution to promoting the teaching process towards the upcoming experience. In fact, STEM, which is being encouraged by the MOET in Vietnam is an extracurricular hands-on activity. STEM also contributes considerably to the development of "Four Cs" skills for high school students. Last but not least, the fourth respondent suggested that English teachers organize extracurricular activities, such as an English-Speaking Club so that students can play and strengthen their "Four Cs" skills. Furthermore, role-play activities and English-speaking competitions must be organized by English teachers in order to enhance communication skills among students.

In short, in order to attain the desired learning outcomes, education must be adapted so as to make it suitable for the learners.

\section{EFL Teachers' Suggestions about Sources of Teaching Materials consistently with "Four Cs"}

As for this part, the third interviewee recommended that the 10-year English textbooks have the strengths because this type of material is suitable for developing "Four Cs" skills for high school students.

"What is clearly visible now is that the Department of Education and Training of An Giang Province has the right to choose textbook, basically for the program. Currently, I feel that this textbook is suitable and it helps teachers to be flexible. I have not studied the remaining textbooks, so I do not know the level. However, from my point of view, after looking at some pages of other books, they are not suitable for the current program of An Giang Province.If possible, I would like to suggest keeping this set of 10-year English textbooksfor the upcoming teaching.", "Yes, that's right. It is suitable for developing those skills." "Obviously, I see that these new books have many activities suitable for developing communication skills for learners. In addition to promoting communication skills, they also enhance other skills such as teamwork skills, creativity and 
DOI: $\underline{10.51386 / 25815946 / i j s m s-v 4 i 5 p 112}$

positivity in their learning process. Altogether, this kind of material with many benefits is much better than the old textbook program, basically.'[T3]

This teacher's suggestion was partially congruous with the findings of Hernawati (2017). According to Hernawati (2017), teachers believe that when conducting the teaching and learning process, it is necessary to link the material of the main subject with issues developing in society, so-called the $21^{\text {st }}$ - century topics so that learners will acquire knowledge of the core subject and apply it in real life.

\section{IMPLICATIONS AND CONCLUSION}

\section{Summary of major findings}

First of all, as for the research first question, the findings of the study showed that the participants (high school EFL teachers in An Giang Province) highly perceived the significance of the $21^{\text {st }}$-century learning and innovation skills (or "Four Cs" skills including communication, collaboration, critical thinking and creativity) for high school students. These participants believed that these "Four Cs" skills are able to contribute considerably to building successful citizens in the future and responsible global citizens in the age of knowledge-based economy and in the age of economic competition between countries. In other words, these "Four Cs" skills play an indispensable role in the learners' future career progression in case the learners sufficiently accumulate their knowledge and these soft skills.

Second, as for the second research question, the findings of this study explored the EFL teachers' eight suggestions to develop 4Cs for high school students related to (1) Instructional Strategies and Techniques to Develop High School Students' four Cs skills, (2) Integrating "Four Cs" into EFL classroom through Hands-on Activities, (3) Integration of "Four Cs" into each specific lesson, (4) Curriculum Development with "Four Cs", (5) Professional Development with "Four Cs", (6) Assessment in Learning and Teaching to develop "Four Cs", (7) Setting up a Learning Environment to Increase Experiential Effectiveness, (8) EFL Teachers' Suggestion about Sources of Teaching Materials consistently with "Four Cs".

From what was discussed above, this research has reached the initial study aims due to the fact that its findings answer two research questions

\section{Pedagogical implications}

In the process of data collection of questionnaire and semi-structured interviews, the interviewees described some suggestions for English teachers, for Foreign Languages Group and for the Department of Education and Training of An Giang Province as well as for education managers.

\subsection{Pedagogical Implications for English teachers}

The findings of the study can emerge the role of the $21^{\text {st }}$ - century teachers. Hence, there are some suggestions to teachers of English. The teachers ought to be willing and self - aware of their role in teaching and integrating four Cs into English class. They should keep up with pedagogical alterations and professional development corresponding to the $21^{\text {st }}$ - century learning and innovation skills.

EFL teachers must clearly educate our learners how to: (i) interact well in lifelike circumstances, both vocally and in writing to grasp the role of effective communication as global citizens; (ii) collaborate with others and value collaboration; (iii) be creative and inventive, do not be afraid to try new things so as to develop new methods to solve issues; (iv) be critical thinkers and problem solvers to sift through the glut of information accessible at their fingertips.

Accordingly, teachers need to equip themselves with solid professional knowledge, English proficiency, and pedagogical skills in classroom management in order to fully promote the role of high school teachers in the digital era or the Industrial revolution era 4.0 because mastering knowledge, instructional techniques, and educational principles compatible with "Four Cs" enables English teachers to successfully integrate these four skills into the classroom. Concurrently, English teachers must also be computer literate in order to fully utilize audio-visual aids in assisting students in gaining knowledge and developing these skills.

Noticeably, with the integrated "Four Cs" teaching method, the teacher will face the initial obstacles. These challenges include devoting time to studying the lesson, selectively searching for "Four Cs"-related teaching materials, designing the appropriate lessons, modifying the teaching content from the textbook, where there are some difficult concepts to understand and making it suitable for the teaching characteristics of "Four Cs". With this learner-cantered strategy, teachers are required to avoid the phenomenon of teachers talking a lot in the 
DOI: $\underline{10.51386 / 25815946 / i j s m s-v 4 i 5 p 112}$

Volume: 4 Issue: 5

September to October 2021

https://www.ijsmsjournal.org

classroom. Unlike the learner-centred approach, teacher-led lessons are traditional lessons in which the teacher delivers a long lecture and the students take notes, which is liable to cause students to lose interest in learning. After facing the initial difficulties, teachers will gradually get used to them, and they also have to maintain integrated teaching throughout the course so that students will no longer be surprised to study with "Four Cs" skills at a higher level.

Simultaneously, the $21^{\text {st }}$ - century teachers also need to understand the students' psychology, grasp the various learning ways of students, learn the different learning needs of students at the beginning of the course, segregate student level, organize classes conformable to PALS model (Peer Assisted Learning Strategies Program_a class-wide peer-tutoring method that caters to each student's individual learning needs. This cooperative learning method pairs students and assigns them the roles of "Coach" and "Player.") and change groups and alter pairs in different sessions to avoid the learners' boredom.

In addition, teachers need to establish a dynamic positive learning environment to promote the learners' role by giving students the opportunities to "learn together with practice", "play and learn" through experiential activities in line with the graders' abilities so that they do not face pressure from learning.

Moreover, the experiential activities organized by the EFL teachers must match the student's interests and correspond with current trends including role play, conversation, situational speaking exercises and ProjectBased Learning approach (scripting, video making, reporting, interviewing, making slide show, making presentation, storytelling, drawing and making presentation to drawing content, ...). Because Project-Based Learning contributes to improving the students' skills not only the $21^{\text {st }}$ - century learning and innovation skills ("Four Cs" or 4Cs) but also other skills such as information collection, data analysis, autonomous learning, management skill and team management for group leaders, negotiation skills, problem-solving skill, and public speaking skill. At the same time, it also turns the graders into responsible and autonomous learners, so teachers should not ignore the student's Project-Based Learning activities.

In particular, PBL should also be combined with blended learning through the use of information technology. Typically, students use computers to search for data on the Internet, select content suitable for project topics, use Microsoft Word applications in creating PowerPoint files for a slide show, and in producing Word files printed to submit to their teachers. In addition, students must also use social networks such as Zalo, Messenger, Zoom Meeting, Viber or Google Meet, etc. to exchange project work in the group, to find the best plan for your team, and finally to create the best product before presenting in front of the class.

Moreover, teachers also need to apply assessment methods suitable to "Four Cs", set a scoring scale in accordance with the standards of "Four Cs" so that the students will be able to take it as motivation, which will promote these 4 skills for students to the maximum.

Above all, in the teaching and learning activities, teachers' roles and graders' roles are required to promote to the maximum. The important matter is whether the classroom succeeds with the objective depends on how the teacher organizes and manages the classroom, in which the cooperation of the learners is needed to be effective

\subsection{Pedagogical Implications for Foreign Languages Group}

There are some comments regarding the importance of professional seminars and foreign language group gatherings. This reveals that the Foreign Languages Group play an essential role in the development of "Four Cs" for high school students. Thus, there are some recommendations to the groups of Foreign Languages.

To begin, the professional seminars and meetings of the foreign language groups must be organized to promote studying how to integrate these "Four Cs" for graders. Mutual class observation of the English teachers should be encouraged in order that the teachers will have more opportunities to advance their self-reflection in their teaching. It is important to share teaching experiences and to give feedback for the teaching performance. This makes teachers not only update their knowledge of teaching but also reflect their teaching practice effectually.

Second, English teachers in the foreign language group should work together to establish curricula and develop their profession on the basis of merging the "Four Cs" into lesson research in order to promote the "Four Cs" for high school students.

Third, teachers in the foreign language group must have mutual support to share their experiences in combining the "Four Cs" skills. The foreign language group should set aside time at school once every two 
DOI: $\underline{10.51386 / 25815946 / i j s m s-v 4 i 5 p 112}$

Volume: 4 Issue: 5

September to October 2021

https://www.ijsmsjournal.org

weeks to study lessons for each skill, lasting 15 to 20 minutes, to discuss how to integrate skills into English class.

Fourth, large-scale meetings or seminars for teachers from many other high schools should be also organized to learn from each other's experiences of integrating "Four Cs", provided that each teacher who also has to have their own expertise has been taught to know what these four skills are and the tactics used to incorporate them into the class. In this way, each teacher will be liable to accumulate many good strategies from other teachers, which will produce the desired learning outcomes.

Fifth, extracurricular activities such as English-Speaking Club, English Speaking Contest, role plays, etc. that should be organized contribute to the learners' "Four Cs" skills. Simultaneously, the PBL approach through group presentations needs to be conducted in the off-session if the official class hour is not adequate.

To summarize, if the MOET in Vietnam requires EFL teachers to teach these "Four Cs", each teacher must make great effort and rely on the mutual support of the foreign language group's teachers to schedule time for studying lessons at school or professional workshops sponsored by the Department of Education and Training of An Giang Province. Besides, Foreign Language Group necessarily invests time into extracurricular activities to partly promote the learners' "four Cs" skills.

\subsection{Pedagogical Implications for the Department of Education and Training of An Giang Province and for education managers}

In light of the findings of the research, the implications for the Department of Education and Training of An Giang Province and for education managers with regards to the development of "4Cs" towards high school students can be drawn out.

There are some suggestions to the Department of Education and Training of An Giang Province regarding fostering "Four Cs" for high school students. Firstly, the results of this study showed that most participants (high school EFL teachers in An Giang Province) were highly aware of the significance of "Four Cs" for high school students and the value of these skills for the learners' future career success. Although the participants desired to promote "Four Cs" for their learners, they felt that they had to face some obstacles such as shortage of experiences in adapting the new English textbooks, lacking strategies of teaching "Four Cs" to the learners, inadequate time allotment for merging "Four Cs" into lessons, the graders' weak level, the learners' low English proficiency, which hindered the participants' integration of "Four Cs" into English lessons. In order to address these challenges above, the participants suggested that the Department of Education and Training of An Giang Province should give EFL teachers good chances to develop their profession and their pedagogical innovation through some following must-to-do things: Firstly, EFL teachers need to be intensively trained strategies and methods of integrating "Four Cs" into English lessons by language experts or university lecturers. These strategies and methods need to be profoundly exploited in the integration of "Four Cs" skills and based on the new ten-year English textbooks with each specific lesson. Especially, it is important for the English teachers to be trained the instructional strategies for three types of graders: a type of excellent graders, that of good ones and that of average ones. Secondly, in addition to the instructional strategies and methods as regards "Four Cs", the EFL teachers should be instructed about the standards and assessments of teaching and learning in terms of these $21^{\text {st }}$-century learning and innovation skills. If teachers use the four Cs skills in English class in the twentyfirst century, they must also use assessment measures that are compatible with the four "Cs" skills' criteria, those that correspond to the assessment framework of the Partnership for the $21^{\text {st }}$ Century. Thirdly, after the interval of training course, the EFL teachers know how to integrate these skills into English classroom; Simultaneously, to make sure that all EFL teachers grasp these strategies, the Department of Education and Training of An Giang Province has to organize seminars for the teachers to learn experiences with each other through observation to the teaching progress of any representative teacher and via the idea contribution of each member on behalf of each foreign language group.

As for the education managers, some recommendations for them are related to developing "Four Cs" for high school students. First, the administrators should spare more time for English teachers to develop their teaching occupation and support their language proficiency as well as their teaching skills. Thus, the institution needs to consider encouraging teachers to have willingness to support their colleagues. In addition, the school managers should create more chances for English teachers to exchange teaching experiences with the teachers of other schools through workshops, conferences and so on. Thanks to this, besides learning the experiences, English teachers can be conscious of instructional strategies of the $21^{\text {st }}$ - century learning and innovation skills of which they can make full use for the next teaching plans. Second, the administrators encourage Foreign Language Groups to organize extracurricular activities such as the Month of the subject of English, English 
DOI: $\underline{10.51386 / 25815946 / i j s m s-v 4 i 5 p 112}$

Volume: 4 Issue: 5

September to October 2021

https://www.ijsmsjournal.org

Speaking Club, English Speaking Contest, and STEM model. As for the STEM model, English teachers who are capable of guiding students on how to get engaged in the STEM model should get involved in it. According to Institute of Educational Management Science (2021), STEM stands for 4 fields of Science, Technology, Engineering, Mathematics integrated and complementary, helping students both master theory and practice, create practical products, apply them to life. They are involved in many STEM topics such as robot programming, rocket making, and so on. From there, students understand more, stimulate creativity from simple products associated with life such as recycled items, learning models, etc. Students are also familiar with modern equipment of the lab such as 3D printers, laser cutters, sensor robots, etc., which helps learners access the products of the 4.0 revolution. With the method of "Learning through practice", "learning and playing", STEM makes students interested in learning. Through exciting games associated with knowledge, learning projects will help students acquire knowledge faster, remember longer and understand more deeply. At the same time, learning for students will become a real passion, a favourite, not a forced one. STEM education also provides students with soft skills such as problem-solving, critical thinking, collaborative skill, communication skill, teamwork skill towards the overall achievement of the team. After completing each product, the members think about how to present and introduce products to attract and answer the questions of listeners.

\section{Limitations of the study}

Although the researcher has reached the research aims, there are regretfully some unavoidable limitations.

First of all, this is the first study carried out in the context of high schools in Vietnam in general and in An Giang Province in particular, so the researcher faced difficulties in collecting data in Vietnam because the concept of four Cs is very new not only for the researcher but also unfamiliar to English teachers involved in questionnaire survey and teachers being interviewed.

Second, the population of participants of the study is slightly limited because there are only 50 EFL high school teachers from high schools in An Giang Province of the Mekong Delta; Accordingly, the results of the research have not reached a broad view to all high school EFL teachers, which is liable to limit the relevance of the findings.

Third, "Four Cs" have not been officially considered an accredited requirement in Vietnam education by the MOET in Vietnam, and most of the participants have not been trained how to integrate "Four Cs" into English classes efficiently, so the teaching experiences of nine interviewees in association with "Four Cs" have not been exploited profoundly towards each lesson of the new English textbooks of the new general education.

Finally, the short time of about six months and the summer time is inadequate for the researcher to fully generalize a large number of instructional strategies and techniques of the participants with regards to a set of the new English textbooks or the ten-year English textbooks in combination with these "Four Cs" skills because they themselves have had a vague impression of these 21 st-century skills.

\section{Recommendations for further studies}

First and foremost, in the light of the findings and discussions of the study, "EFL Teachers' Perceptions about "Four Cs" for EFL Students in the Context of High Schools" in Vietnam for further studies are suggested that further studies can be carried out in a wide of context with a variety of participants from the different context of education like primary or secondary schools to generalize their beliefs and practice.

Also, if the MOET in Vietnam declares the "Four Cs" skills to be an official requirement in Vietnam education, it will be crucial to conduct some experimental studies at all levels of the Vietnamese educational system to determine the best instructional methods for EFL teachers for all of the EFL teachers in Vietnam to apply these skills in English classes effectively and systematically. Certainly, this will entail the studies on curriculums, standards, professional development, assessment forms in learning and teaching in conformity with "4Cs".

Finally, it will be exciting if further research is possibly conducted to investigate native teachers' perceptions and practices of "Four Cs" skills. Through their perceptions and practices of "Four Cs" skills, future researchers will also exploit the native teachers' interesting instructional strategies when they integrate these learning and innovation skills into English classes in the context of schools in Vietnam. 
DOI: $\underline{10.51386 / 25815946 / \mathrm{ijsms}-\mathrm{v} 4 \mathrm{i} 5 \mathrm{p} 112}$

\section{ABOUT THE AUTHOR}

Vuong Thi Huyen Tran has been working as an English teacher for 12 years in An Giang Province, Vietnam. She completed a Bachelor's degree in English Translation in 2002. She has been an MA student at Can Tho University so far. She is fond of researching the themes in terms of pedagogical reforms and professional development.

\section{REFERENCES}

[1] Albahlal, F. S. (2019). The integration of 21th century skills into English language learning. Journal of Applied Linguistics and Language Research. Retrieved June 10, 2021, from http://www.jallr.com/index.php/JALLR/article/view/1027.

[2] American Management Association. (2011, May 16). AMA 2010 Critical Skills Survey: Executive Summary. Retrieved from www.p21.org/documents/Critical\%20Skills\%20 Survey\%20Executive\%20Summary.pdf.

[3] AminuddinBaki Institution. (2017). Handbook of 21st Century Learning Implementation. Negeri Sembilan: AminuddinBaki Institution.

[4] Beetham, H., \& Sharpe, R. (2013). Rethinking pedagogy for a Digital age: Designing for 21st Century learning (Vol. 711). New York, NY: Routledge.

[5] Bloom, B.S. (Ed.) (1956) Taxonomy of educational objectives: The classification of educational goals: Handbook I, cognitive domain. New York; Toronto: Longmans, Green.

[6] Brown, H.Douglas. (2001). Teaching by Principles. An Interactive Approach to Language Pedagogy. Englewood Cliffs: Prentice Hall.

[7] Brown, P., Lauder, H., Ashton, D., Yingje, W., \& Vincent-Lancrin, S. (2008). Education, globalisation and the future of the knowledge economy. European Educational Research Journal, 7(2), 131-156. https://doi.org/10.2304/eerj.2008.7.2.131

[8] Brultey, Y. (2015). "21st Century Education: A Practical Application of the 4Cs in the Mexican ESL Classroom.”kathleenmercury. Retrieved from https://www.kathleenmercury.com/uploads/2/2/7/4/22743302/article_4cs-yohann_brultey-11-5-2015_.pdf.

[9] Bộgiáodụcvàđàotạo. (2019, March 5). ChươngTrìnhPhổThôngMới Môn Tiếng Anh: Họcsinhphảitựhọcnhiềuhơn. Cổngthông tin điệntửBộGiáodụcvàĐàotạo. Retrieved May 2, 2021, from https://www.moet.gov.vn/giaoducquocdan/giao-duc-trunghoc/Pages/Default.aspx?ItemID=5853.

[10] Bộgiáodụcvàđàotạo. (2020, August 14). VănBảnChỉĐạo, ĐiềuHành. Retrieved July 20, 2021, from https://www.moet.gov.vn/vanban/vbdh/Pages/chi-tiet-van-ban.aspx?ItemID=2784.

[11] Chiruguru, S. (2020, March 20). (PDF) The Essential Skills of 21st Century Classroom (4cs). ResearchGate. Retrieved September 20, 2021, from https://www.researchgate.net/publication/340066140_The_Essential_Skills_of_21st_Century_Classroom_4Cs.

[12] Cho, H., Song, K., \& Lee, J.-Y. (2018). Korean immigrant parents' involvement in children's Biliteracy development in the U.S. context. Advances in Early Childhood and K-12 Education, 344-359. https://doi.org/10.4018/978-1-5225-3955-1.ch017

[13] Corbin, J., \& Strauss, A. L. (2008). Basics of Qualitative Research (3rd Edition). Thousand Oaks: SAGE Publication s, Inc.

[14] Dantri.com.vn. (2016, April 15). 4 NhómKỹNăngThiếtYếuBốMệiệtCầntrangBị Cho Con ở ThếKỷ 21. BáođiệntửDânTrí . Retrieved September 10, 2021, from https://dantri.com.vn/giao-duc-huong-nghiep/4-nhom-ky-nang-thiet-yeu-bo-me-viet-can-trang-bi-cho-cono-the-ky-21-20160415095950579.htm.

[15] Dung Viet. (2020, May 6). KỹNăngmềm - ChìaKhóaCủaThànhcôngvàHạnhPhúc. GiáodụcViệt Nam. Retrieved July 10, 2021, from https://m.giaoduc.net.vn/giao-duc-24h/ky-nang-mem-chia-khoa-cua-thanh-cong-va-hanh-phuc-post209135.gd.

[16] Erdoğan, V. (2019, November). Integrating 4C skills of 21st century into 4 language skills in EFL classes. International Journal of Education and Research. Retrieved from https://www.ijern.com/journal/2019/November-2019/09.pdf.

[17] Fraenkel, J. R., Wallen, N. E., \& Hyun, H. H. (2012). How to design and evaluate research in education ( $8^{\text {th }}$ Ed.). New York: McGraw-Hill Humanities/Social Sciences/Languages

[18] Gay, L. R., Mills, G. E., \&Airasian, P. (2012). Educational research: Competences for analysis and applications. Pearson Education. P. 438.

[19] Gardner, H. (2006). Five Minds for the future. MA: Harvard Business School Press.

[20] Halvorsen, A. (2018, August 21). University of Oregon Libraries. 21st Century Skills and the "4Cs" in the English Language Classroom. Retrieved September 20, 2021, from https://scholarsbank.uoregon.edu/xmlui/handle/1794/23598?show=full.

[21] Handayani , N. (2017). Becoming the Effective English Teachers in the 21st Century: What Should Know and What Should Do? UNIMUS ELLiC. 
DOI: $\underline{10.51386 / 25815946 / \mathrm{ijsms}-\mathrm{v} 4 \mathrm{i} 5 \mathrm{p} 112}$

Volume: 4 Issue: 5

September to October 2021

https://www.ijsmsjournal.org

[22] Hernawati, S. S. (2017). What Makes Effective Teaching in the 21st Century. UNIMUS ELLiC. Retrieved from https://jurnal.unimus.ac.id/index.php/ELLIC/article/download/2472/2498.

[23] Hung, T. (2018, January 19). ChươngtrìnhmônTiếng Anh mớitâptrungnănglựcgiaotiếpcủahocsinh. Vietnamnet. Retrieved September 10, 2021, from https://vietnamnet.vn/vn/giao-duc/hoc-tieng-anh/chuong-trinh-mon-tieng-anh-moi-o-pho-thong-xac-dinh-nang-lucgiao-tiep-la-muc-tieu-424748.html.

[24] Khang, P. T. (2013, March 4). KỹNăngMềmvàSinhViênViệt Nam Hiện Nay. PhạmTuấnKhang. Retrieved July 5, 2021, from https://phamtuankhang.wordpress.com/2013/03/04/ky-nang-mem-va-thuc-trang-cua-sinh-vien-viet-nam-hien-nay/.

[25] Klaus, P. (2010, March 6). Neither men nor mice. The New York Times. Retrieved June 15, 2021, from https://www.nytimes.com/2010/03/07/jobs/07preoccupations.html.

[26] Levy, F., \& Murnane, R. J. (2012). The New Division of Labor: How Computers Are Creating the Next Job Market. Princeton University Press.

[27] Michaels, R., Truesdell, E., \& Brown, B. (2015). Incorporating 21 st-century skills into teacher preparation programs: A collaborative approach. Journal of Scholastic Inquiry: Education, 5(1), 47-72.

[28] National Education Association. (2010). Preparing 21st Century Students for a Global Society: An Educator's Guide to the "Four Cs". Retrieved from http://www.nea.org/assets/docs/A-Guide-to-Four-Cs.pdf.

[29] Pardede, P. (2020). Integrating the 4Cs into EFL Integrated Skills Learning, 6(1), 71-85. https://doi.org/10.33541/jet.v6i1.190

[30] Quad, A. D. J. P. (2016, March 7). Research methodology in education. Research Methodology in Education - An LLED Manual. Retrieved September 20, 2021, from https://lled500.trubox.ca/2016/225.

[31] Richard M. Cash (November 12, 2018). 8 Ideas for Building Intrinsic Motivation to Learn in Students.

[32] Robinson, K. (2011, May 16). "Ken Robinson Says Schools Kill Creativity.” Speech. TED Talks. Retrieved from http://www.ted.com/talks/ken_robinson_says_schools_kill_creativity.html.

[33] Roekel, D. V. (2017). Preparing 21st Century Students for a Global Society: An Educators Guide to 4C'S (NEA,2017). The National Education Association (NEA). Retrieved from http://www.nea.org/assets/docs/A-Guide-to-Four-Cs.pdf

[34] Rotherham, Andrew J.; Willingham, Daniel T. (Spring 2010). "21st-Century" Skills: Not New, but a Worthy Challenge. American Educator, v34 n1 p17-20

[35] Şahin, H. \& Han, T. (September, 2020). EFL Teachers’ Attitude Towards $21^{\text {st }}$ - Century Skills: A Mixed- Methods Study.

[36] Shaffer (July 11, 2018) CATEGORIES: Blog Educators Parents: 10 Benefits of Project-Based Learning. Retrieved from https://www.destinationimagination.org/blog/10-benefits-of-project-based-learning/\#: :text=10\%20Benefits\%20of\%20Project-

Based $\% 20$ Learning $\% 201 \% 20$ Collaboration $\% 3$ A $\% 20$ Relationships,reflecting $\% 20$ on $\% 20$ and $\% 20$ celebrating $\% 20$ their $\% 20$ progress $\% 2$ 0and\%20accomplishments

[37] Sohaya, E. M. (2020). Blended learning and 4Cs: Trends in the new normal life of education, globalization and the next decade. Proceedings of the 5th Annual International Seminar on Transformative Education and Educational Leadership (AISTEEL 2020). https://doi.org/10.2991/assehr.k.201124.019

[38] Stauffer, B. (2020, May 7). What are the 4 C's of 21st century skills? Digital Curriculum for CTE \& Elective Teachers. Retrieved April 9, 2021, from https://www.aeseducation.com/blog/four-cs-21st-century-skills.

[39] Surowiecki, J. (2005). The Wisdom of Crowds. Anchor Books.

[40] Tapchicongthuong.vn.

$(2019$, January

2). NhữngYếuTốẢnhHưởngĐếnViệcHọcTậpKỹNăngMềmCủaSinhViênTrongMôiTrườngĐạiHọc. TạpchíCôngThương. Retrieved July 3, 2021, from https://tapchicongthuong.vn/bai-viet/nhung-yeu-to-anh-huong-den-viec-hoc-tap-ky-nang-mem-cua-sinh-vien-trongmoi-truong-dai-hoc-59005.htm.

[41] Trilling, B., \& Fadel, C. (2009). 21st century skills: Learning for life in our times. Jossey-Bass/Wiley.

[42] Trilling, B., \& Fadel, C. (2012). What talents do young people need to thrive in the 21 st century? A game of skills. Royal Society for the Encouragement of Arts, Manufactures and Commerce. Journal, 22, 10-15.

[43] Yue-Yi, H. (2016, August). From Drills to Skills? Cultivating Critical Thinking, Creativity, Communication, And Collaboration through Malaysian Schools. Penang institute. Retrieved from https://penanginstitute.org/wpcontent/uploads/jml/files/research_papers/HwaYY_Four_Cs_working_paper_28October2016.pdf. 